\title{
A Tale of Two Provinces: IMPOSING GREENHOUSE GAS EMISSIONS CONSTRAINTS Through LAW AND POLICY IN ALBERTA AND BRITISH COLUMBIA
}

\author{
Teresa MeAdows AND TONy CROSSMAN*
}

In Canada, there has been much discussion regarding the best approach to reducing greenhouse gas emissions. These discussions have moved beyond theory in two provinces that approached the issue from two very different vantage points. Alberta and, more recently, British Columbia have introduced their own legislative responses to reducing emissions on a provincial level. This article provides an overview of the "tale" of two provinces grappling with some of the thorniest greenhouse gas regulatory issues, including the establishment of emission limits, developing frameworks to govern processes and practice for carbon trading, and developing mechanisms to address regulation and funding of carbon capture and sequestration projects. The article concludes with a review of some of the challenges created for the oil and gas sector by the differing visions incorporated in the legislative and policy responses of the two jurisdictions, and identifies key challenges to harmonization of these efforts across Canada.
Au Canada, on a beaucoup parlé de la meilleure manière de réduire les émissions de gaz à effet de serre. Ces discussions ont évolué au-delà de la théorie dans deux provinces qui ont abordé la question à partir de deux points de vue très différents. L'Alberta et tout dernièrement la Colombie-Britannique ont introduit leurs propres réponses législatives à la réduction des émissions sur le plan provincial. Cet article donne un aperçu de "l'histoire » de deux provinces aux prises avec les questions de règlementation gazière les plus épineuses, incluant l'établissement de limites d'émission, l'élaboration de démarches régissant les processus et les pratiques pour l'échange de droits d'émission de carbone ainsi que l'élaboration de mécanismes abordant la réglementation et le financement de projets de capture et de séquestration de carbone. L'article se termine sur une récapitulation de certains problèmes que le secteur pétrolier et gazier a créés au moyen de différentes visions incorporées dans les réponses législatives et politiques des deux ressorts, et identifie les défis clés que présente l'harmonisation de cet effort à travers le Canada.

\section{TABLE OF CONTENTS}

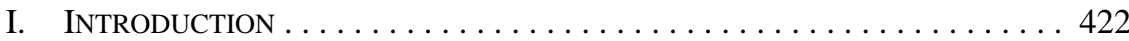

A. Oil And Gas Sector Overview . . . . . . . . . . . . . . . . . 422

B. EMISSIONS PROFILES ..................... 426

C. Climate Change Impacts . . . . . . . . . . . . . . . . . . . 429

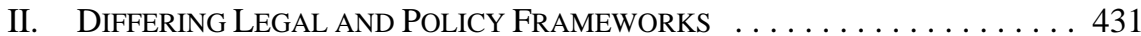

A. Climate Change Policy Development . . . . . . . . . . . . . . 431

B. Current Legislative Initiatives $\ldots \ldots \ldots \ldots \ldots \ldots \ldots \ldots$

III. CHALLENGES AND OPPORTUNITIES FOR THE

OIL AND GAS SECTOR . . . . . . . . . . . . . . . . . . . . . . . 452

A. AlBERTA .......................... 452

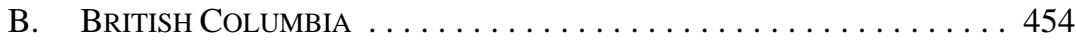

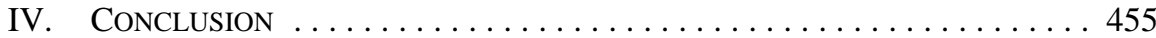

Miller Thomson, LLP. Ms. Meadows is with the Edmonton office and Mr. Crossman is with the Vancouver office. 


\section{INTRODUCTION}

In the spring of 2008, the federal government identified that that there were no less than 200 provincial and territorial initiatives designed to reduce greenhouse gas (GHG) ${ }^{1}$ emissions. ${ }^{2}$ Ranging from broad policy commitments to detailed regulatory frameworks, these initiatives reflect the considerable diversity of each region's economic, geographic, and resource endowment, as well as the region's politics. ${ }^{3}$ Although designed to meet the same goal of emissions reductions, the approaches vary considerably with some jurisdictions opting for voluntary approaches while others have begun to implement prescriptive regulatory frameworks specifically designed to address these emissions. To illustrate that these divergent approaches have the potential for varied impacts on the oil and gas industry going forward, the authors have analyzed the stark contrasts between the oil and gas sector profiles, GHG profiles, policies, and regulatory responses of two western Canadian jurisdictions. Alberta and, more recently, British Columbia, have each crafted unique approaches to GHG emissions reductions that reflect their specific emissions profiles, policies, and politics. As the authors suggest, there are undoubtedly lessons to be learned and challenges and opportunities presented by the approaches in each province, not the least of which is that harmonization on a national or international level will be as challenging as it is necessary.

\section{A. Oil And Gas Sector Overview}

\section{ALBERTA}

As recognized in Alberta's provincial energy strategy, the prosperity of Alberta is inextricably linked to the energy industry (the oil and gas sector in particular):

Energy has underwritten the story of our province. Today in Alberta, the energy sector directly and indirectly is the single largest contributor to provincial Gross Domestic Product, income, employment and government revenues. It comprises more than two-thirds of our exports.

By “greenhouse gases” we mean those gases that have been defined as such under Annex A to the Kyoto Protocol to the United Nations Framework Convention on Climate Change, 11 December 1997, 2303 U.N.T.S. 148 at 218 (entered into force 16 February 2005) [Kyoto Protocol], and that are currently reported in Environment Canada, National Inventory Report 1990-2006: Greenhouse Gas Sources and Sinks in Canada (Gatineau: Environment Canada, 2008) at 2, online: Environment Canada <http:// www.ec.gc.ca/pdb/ghg/inventory_report/2006_report/tdm-toc_eng.cfm> [National Inventory 2006] (carbon dioxide $\left(\mathrm{CO}_{2}\right)$; methane $\left(\mathrm{CH}_{4}\right)$; nitrous oxide $\left(\mathrm{N}_{2} \mathrm{O}\right)$; sulphur hexafluoride $\left(\mathrm{SF}_{6}\right)$; perfluorocarbons (PFCs); and hydrofluorocarbons (HFCs)).

2 Government of Canada, Turning the Corner: Taking Action to Fight Climate Change (Ottawa: Government of Canada, 2008) at 6, online: Environment Canada <http://www.ec.gc.ca/doc/viragecorner/2008-03/pdf/572_eng.pdf>.

3 For a snapshot of some of the initiatives undertaken in 2007-2008 that involved the measurement of greenhouse gas emissions, developing sources of renewable energy, creating a biofuels and hydrogen distribution system, creating an inventory of research currently in progress, educating our citizens, encouraging energy efficiency and conservation, capturing methane gas, and adapting to climate change, see The Council of the Federation, Canada's Premiers: Taking Action on Climate Change - A Report on Progress Achieved Since August 2007 (Ottawa: Council of the Federation, 2008), online: Council of the Federation <http://www.councilofthefederation.ca/pdfs/CCCommPiece_0718-FINAL. pdf >. 
Alberta produces about five trillion cubic feet (Tcf) of natural gas, 250 million barrels of conventional oil, 500 million barrels of bitumen (a semi-solid form of crude oil) and ... more than 30 million tonnes of coal each year. ${ }^{4}$

Although conventional oil and gas resource developments were the backbone of the industry historically, conventional oil production in Alberta peaked in the 1970s and conventional gas production has also peaked and is on the decline, reflecting the maturity of the area's conventional oil and gas fields. ${ }^{5}$ As a result, it is expected that Alberta's oil and gas sector will increasingly turn to "unconventional sources," such as coalbed methane, shale gas, and, of course, the continued development of Alberta’s considerable oil sands.

A review of western Canada's total crude oil production indicates that in 2006, for the first time, slightly more than half of production (1.1 million barrels per day) was derived from oil sands, surpassing the 1.0 million barrels per day from conventional crude oil sources. ${ }^{6}$ With the oil sands comprising the second largest known petroleum reserve in the world, containing an estimated 1.71 trillion barrels of bitumen, ${ }^{7}$ Alberta has a dominant role to play in supplying oil from unconventional sources, but is also acutely vulnerable to regulatory initiatives to ban hydrocarbons from unconventional sources unless GHG emissions are reduced. ${ }^{8}$ In the spring of 2009, the Canadian Association of Petroleum Producers described Alberta's future role in the overall trend of unconventional hydrocarbon development required to meet rising global energy demand:

\footnotetext{
However, it also true that global energy demand is projected to increase significantly — forecasts suggest a 50 per cent increase by 2030 and a doubling by 2050 — driven by population growth and aspirations for higher standards of living in the developing world. Most reputable forecasters agree that hydrocarbons are going to continue to provide the majority of energy supply over this period. With a decreasing supply of conventional hydrocarbons, unconventional (both oil and gas) are going to play an increasing role in the energy supply mix. In this regard, Western Canada is uniquely positioned to be a key part of the supply equation for some time to come. ${ }^{9}$
}

Government of Alberta, Launching Alberta's Energy Future: Provincial Energy Strategy (Edmonton: Alberta Energy, 2008) at 5, online: Alberta Energy <http://www.energy.gov.ab.ca/Org/pdfs/AB_ ProvincialEnergyStrategy.pdf $>$ [Alberta's Provincial Energy Strategy].

$5 \quad$ Ibid. at 6 .

$6 \quad$ Canadian Association of Petroleum Producers (CAPP), Crude Oil: Forecast, Markets \& Pipeline Expansions (Calgary: Canadian Association of Petroleum Producers, 2009) at 3-4, online: CAPP <http:// www.capp.ca/GetDoc.aspx?DocID=138295>.

$7 \quad$ Government of Alberta, Responsible Actions: A Plan for Alberta's Oil Sands (Edmonton: Alberta Treasury Board, 2009), online: Alberta Treasury Board <http://treasuryboard.alberta.ca/docs/GOA_ ResponsibleActions_web.pdf $>$ [A Plan for Alberta's Oil Sands].

8 For example, see the considerable discussion generated in Alberta regarding s. 526 of the United States Energy Independence and Security Act of 2007, 42 U.S.C. § 17142 (2007), which had the potential to prevent all federal U.S. agencies from procuring fuel produced from unconventional sources (such as the oil sands) unless the GHG emissions associated with such fuels are less than or equal to conventional sources.

9 Dave Collyer, President of the Canadian Association of Petroleum Producers (Speech to the Calgary Chamber of Commerce, 17 March 2009) at 3, online: CAPP <http://www.capp.ca/GetDoc.aspx?dt= PDF\&docID $=149090>$. 
In 2007, Alberta's contribution to Canada's oil and gas production was approximately 73 percent of national production, amounting to revenues of $\$ 80.4$ billion..$^{10}$ In 2006-2007, nonrenewable resource revenue accruing to the province amounted to more than $\$ 12$ billion, which was more than 30 percent of the total provincial government revenue. ${ }^{11}$ As recently as the second quarter of 2008, forecasts regarding Alberta's economic growth in the oil and gas sector suggested that for the period from 2008-2017, investments in excess of \$116 billion were anticipated in oil sands development and, over that same time period, annual average investments of $\$ 25$ billion were projected for the conventional oil and gas extraction industries. ${ }^{12}$

Needless to say, the picture in 2009 has changed considerably. Although an Alberta economic update issued in February 2009 noted that high energy prices in the first part of 2008 partially cushioned the effect of the global recession on Alberta, growth in Alberta's gross domestic product (GDP) in 2008 was nonetheless limited to 0.4 percent. ${ }^{13}$ In 2009, for the first time in a decade, Alberta's economy is predicted to contract by at least 2.4 percent, although modest growth of 2.9 percent is predicted to return in $2010 .{ }^{14}$ Both the global credit crisis and volatility in oil prices have combined to cause huge cuts to investment in energy production. ${ }^{15}$ In addition, with significant job losses in the first quarter of $2009,{ }^{16}$ including direct job losses in the oil and gas sector, ${ }^{17}$ the downturn in this sector has had an immediate and tangible impact on most Albertans. Citing the projection that activity in Alberta's oil and gas sector is expected to drop more than 27 percent in 2009, the Province introduced a threepoint incentive program to increase activity in the conventional oil and gas sector in March $2009,{ }^{18}$ and additional stimulus is expected.

Although one might assume that given the drastic effects of the global economic conditions on the oil and gas sector, which in turn are having a significant impact on the Province's economic and employment picture in the near-term, the focus on environmental issues would yield to economic drivers, this is not, in fact, the case. As recognized in

10 Natural Resources Canada, Important Facts on Canada's Natural Resources (as of October 2008) (Ottawa: Her Majesty the Queen in Right of Canada, 2009) at 14-15, online: Natural Resources Canada <http://www.nrcan-rncan.gc.ca/stat/docs/important-eng.pdf> [Important Facts on Canada's Natural Resources].

11 Government of Alberta, Energy Facts, online: Alberta Energy <http://www.energy.gov.ab.ca/About_ Us/984.asp>.

12 Energy Resources Conservation Board (ERCB), Alberta's Energy Reserves 2007 and Supply/Demand Outlook 2008-2017, ST98-2008 (Calgary: Energy Resources Conservation Board, 2008) at 1-17, online: ERCB <http://www.ercb.ca/docs/products/STs/ST98-2008.pdf> [ERCB ST98-2008].

13 See the summary of the Conference Board of Canada's spring forecast cited in Government of Alberta, "Weekly Economic Review" (31 July 2009) at 3, online: Alberta Finance and Enterprise <http://www. finance.gov.ab.ca/aboutalberta/economic_bulletins/2009/0731.pdf> [Weekly Economic Review].

14 Ibid.

15 See the discussion regarding this trend in Government of Alberta, 2009 Economic Update (Edmonton: Alberta Finance and Enterprise, 2009) at 5, online: Legislative Assembly of Alberta <http://www. assembly.ab.ca/lao/library/egovdocs/2009/altd/171915.pdf $>$, where the predictions from the CAPP are cited that predict investment in non-conventional (typically oil sands) energy production will drop by 50 percent in 2009.

16 For example, in February 2009 alone there were an estimated 23,700 jobs lost in Alberta: see Government of Alberta, “Labour Force Developments” (13 March 2009), online: Alberta Finance and Enterprise <http://www.finance.gov.ab.ca/aboutalberta/labour_force/2009/2009_02_developments.pdf>. In the spring of 2009, the CAPP estimated that 8,300 of the jobs lost in Canada in February 2009 were in the mining, oil, and gas extraction sector and these were primarily lost in Alberta: see Collyer, supra note 9 at 10 .

18 Government of Alberta, Talk about the Energy Incentive Program (Edmonton: Alberta Energy, 2009), online: Alberta Energy <http://www.energy.gov.ab.ca/Org/pdfs/FS_incentive_pgm.pdf>. 
Alberta's Provincial Energy Strategy ${ }^{19}$ and A Plan for Alberta's Oil Sands,${ }^{20}$ the potential for recovery and growth in this sector will be directly affected by environmental challenges as well. The growing global focus on climate change issues and GHG emissions in particular will require that the government and industry commitments be viewed as genuine and effective in reducing the carbon footprint of energy production, particularly for unconventional sources such as oil sands.

Given the Province's considerable energy reserves and predicted global energy demands in the longer term, all indications suggest that the Province's economic recovery will be once more led by the oil and gas sector, but it will not be a return to business as usual. Significant policy drivers have shifted and global markets are demanding that measures to reduce GHGs and mitigate the effects of global climate change become part of the resource development equation. As a result, despite recent economic events, Alberta's hope for a return to the prosperity of the last ten years is tied not only to the oil and gas sector, but also to the success of its policy and regulatory response to climate change, as discussed in the sections that follow.

\section{BRITISH COLUMBIA}

The oil and gas sector has become a significant part of the British Columbia economy providing tens of thousands of jobs, investing $\$ 4.6$ billion in British Columbia in 2005, and contributing 7 percent, or $\$ 1.95$ billion, annually to British Columbia revenues. ${ }^{21}$ British Columbia now has the second largest oil and gas sector in Canada, while the centre of British Columbia's oil and gas sector in the northeast of British Columbia is experiencing population increases above the provincial average. ${ }^{22}$ At the same time that British Columbia saw a significant increase in oil and gas development, there was a resulting increase in the GHG emissions from these activities.

In 2007, the British Columbia government announced that British Columbia would be a leader in addressing climate change, ${ }^{23}$ acknowledging that the science was clear and that there was no time for procrastination. ${ }^{24}$ Through its Climate Action Plan ${ }^{25}$ and subsequent policy and legislative initiatives, British Columbia put its plan into action through such measures as legislating targeted GHG emission reductions, creating a carbon neutral public sector, implementing a revenue neutral carbon tax, and establishing a framework for a cap and trade system.

Supra note 4.

Supra note 7.

Government of British Columbia, The BC Energy Plan: A Vision for Clean Energy Leadership (Victoria: Ministry of Energy, Mines and Petroleum Resources, 2007) at 29, online: Government of British Columbia <http://www.energyplan.gov.bc.ca/PDF/BC_Energy_Plan.pdf > [BC Energy Plan].

Ibid. at 34.

The Honourable Iona Campagnolo, "Speech from the Throne" (Presented at the Opening of the Third Session, Thirty-Eighth Parliament of the Province of British Columbia, 13 February 2007) at 12-13, online: Legislative Assembly of British Columbia <http://qp.gov.bc.ca/38th3rd/Throne_Speech_ 2007.pdf>.

$24 \quad$ Ibid. at 12.

Government of British Columbia, Climate Action Plan (Victoria: Ministry of Environment, 2008), online: LiveSmart BC <http://www.livesmartbc.ca/attachments/climateaction_plan_web.pdf $>$ [BC Climate Action Plan]. 
As part of British Columbia's plan to reduce GHG emissions in the oil and gas sector, which is the second to largest GHG emitting sector in British Columbia, the government will eliminate all routine flaring at oil and gas producing wells and production facilities by 2016, with an interim goal to reduce flaring by 50 percent by 2011. Although this will have obvious implications for oil and gas operations, climate change impacts will have broader implications for the sector, including an intended change in demand for oil and gas as a result of government climate change policies, and requiring exploration, development, and operations to adapt to changing climatic conditions. All of this will have to take place in the current global economic downturn and an era of lower resource prices.

\section{B. EMISSIONS PROFILES}

\section{ALBERTA}

Alberta's policy and regulatory response to GHG emissions and climate change issues has been shaped by its unique GHG emissions profile. According to the most recent annual inventory of human induced GHG emissions and removals in 2006, Alberta generated 234 megatonnes (Mt) ${ }^{26}$ of GHG emissions. ${ }^{27}$ According to Canada's 2006 census, despite Alberta's population accounting for about 10 percent of Canada's total population, ${ }^{28}$ Alberta's GHG emissions at the same time comprised approximately one third of Canada's total emissions. ${ }^{29}$ By extension, it is perhaps not surprising that individual Albertans are the second highest per capita GHG emitters in the country, ${ }^{30}$ emitting 69.5 tonnes of GHG per Albertan each year. ${ }^{31}$ This is three times the national average of per capita emissions (22.1 tonnes) and almost seven times greater than Canada's lowest per capita emitter, Quebec, where per capita emissions are approximately 10.7 tonnes annually. ${ }^{32}$

Despite being characterized as "dirty oil" in part due to its carbon footprint, the contribution of oil sands mining to Alberta's total emissions in 2006 as expressed in all mining, which includes oil and gas extraction from oil sands, was $11.4 \mathrm{Mt}$ or about 5 percent of the 2006 totals. ${ }^{33}$ However, when combined with fossil fuel industries, pipelines, fugitive emissions from coal mining, and fugitive emissions from oil and natural gas, the overall emissions attributed directly to all fossil fuel production in Alberta (including oil sands) were 92.4 Mt, or about 40 percent of Alberta’s 2006 total GHG emissions. ${ }^{34}$

Alberta's population in 2006 was 3.3 million people and Canada's total population was 31.6 million: see Statistics Canada, “Alberta” 2006 Community Profiles (24 July 2009), online: Statistics Canada <http://www12.statcan.ca/census-recensement/2006/dp-pd/prof/92-591/details/page_Print-Imprimer. cfm?Lang=E\&Geo1=PR\&Code1 $=48 \&$ Geo2 $=$ PR\&Code2 $=01 \&$ Data $=$ Count \&SearchText $=$ Alberta\& SearchType=Begins $\&$ SearchPR $=01 \& B 1=$ All\&Custom $=>$.

National Inventory 2006, supra note 1 at 584.

Saskatchewan was the highest per capita emitter for 2006 with emissions of 72.9 tonnes: see ibid. at 546 .

Ibid. at 550

Ibid. at 24, 535.

Ibid. at 584 .

Ibid. 
There is no doubt that Alberta's emissions profile is very much reflective of its dominant position in Canada as a producer of energy. In 2006, Alberta provided 64 percent of Canada's primary energy production. ${ }^{35}$ However, in addition to Alberta's clear role as a fossil fuel energy producer, to truly complete Alberta's emissions picture it must also be remembered that Alberta's electricity and heat generation consumption requirements are met almost exclusively via the combustion of coal and natural gas. For example, in 2007, Albertans relied on coal-fired power generation to produce 62 percent of the province's electricity, followed by natural gas at 32 percent, hydro at 3 percent, and wind and biomass at 3 percent. $^{36}$ Alberta's electricity and heat generation industry produced $53.8 \mathrm{Mt}$ of emissions (approximately 23 percent of Alberta's total in 2006). ${ }^{37}$ This mix is unlikely to be altered significantly in the near future because, despite increases in wind-power development in recent years, plans suggest that increases in electricity production over the next 10 years will primarily involve the development of a supercritical coal-fired generation facility and an integrated gasification combined cycle coal generation facility. ${ }^{38}$ Although the Province has raised the possibility of considering alternative energy sources to meet future demand, including nuclear ${ }^{39}$ and alternatives, the key focus for the near future appears to be consuming fossil fuels in a "far cleaner way" (that is, gasification and carbon sequestration), rather than moving to radically alter the current energy mix. ${ }^{40}$

In terms of compliance with the Kyoto Protocol $^{41}$ (6 percent reduction from 1990 levels of emissions), as is the case in many other Canadian jurisdictions, Alberta is far from achieving reductions below 1990 levels, exceeding 1990 levels by 37 percent in $2006 .{ }^{42}$ With significant jumps in commodity prices, and high rates of growth in the period from 20012006, ${ }^{43}$ Alberta's increased emissions were fuelled by unprecedented economic and population growth. ${ }^{44}$ However, as most Albertans will be quick to point out, although Alberta has increased its total GHG emissions by 37 percent since 1990, Alberta's contribution to Canada's GDP increased by more than 90 percent over the same period. Consequently, when viewed on the basis of Mt of GHG produced per billion dollar contribution to GDP, Alberta's “emissions intensity" 45 has increased by more than 25 percent.

Important Facts on Canada's Natural Resources, supra note 10 at 13.

ERCB ST98-2008, supra note 12 at 9-8.

National Inventory 2006, supra note 1 at 584. The remaining 37 percent of annual emissions are primarily attributed to transportation, agricultural, industrial, and waste management sources.

National Energy Board, Energy Brief: Coal-Fired Power Generation - An Overview (Calgary: National

Energy Board, 2008) at 1, online: National Energy Board <http://www.neb.gc.ca/clfnsi/rnrgynfmtn/nrgyrprt/lctrcty/clfrdpwrgnrtn2008/clfrdpwrgnrtnnrgybrf-eng.pdf>.

For an indication of the issues likely to be canvassed during the development of nuclear power capability in the Province see the recently released Nuclear Power Expert Panel, Report on Nuclear Power and Alberta (Edmonton: Alberta Energy, 2009), online: Alberta Energy <http://www.energy. alberta.ca/Electricity/pdfs/NuclearPowerReport.pdf $>$.

See the discussion of "Clean Energy Production" in Alberta's Provincial Energy Strategy, supra note 4 at 23-24.

Supra note 1 , art. 3.

National Inventory 2006, supra note 1 at 550.

In the period from 2002-2007, the average rate of economic growth in Alberta averaged to 4.7 percent per year: see ERCB ST98-2008, supra note 12 at 1-17.

National Inventory 2006, supra note 1 at 551.

In this context, we mean the emissions (in Mt) divided by the gross domestic product (GDP) in billions of dollars, as calculated in the National Inventory 2006, ibid. 
The projections of Alberta's emissions provided at the time the government unveiled Alberta's 2008 Climate Change Strategy: Responsibility/Leadership/Action in January $2008^{46}$ were based on a continuation of the significant economic growth and associated increases in employment and population growth, all leading to increased emissions. At the rates of population growth seen in the years 2001-2006, (approximately 10 percent growth every five years), Alberta's population was predicted to double between 2006 and the mid-2030s. ${ }^{47}$ On this basis, Alberta's emissions (assuming no mitigation was undertaken) were projected to swell to 305 Mt by 2020 and 400 Mt by 2050 (this is more than double the 1990 emissions of $172 \mathrm{Mt})^{48}$

In the late winter of 2008 it appeared that the only way emissions would be greatly reduced was if the mitigation measures proposed under the Alberta 2008 Strategy were implemented. Consequently, the Alberta 2008 Strategy proposed three primary mechanisms to achieve reductions: increased energy conservation and efficiency; carbon capture and sequestration; and greening energy production, resulting in a total reduction target of $50 \mathrm{Mt}$ less than the business as usual projections by 2020 and a $200 \mathrm{Mt}$ reduction over business as usual by $2050 .^{49}$

As indicated in the discussion of Alberta's oil and gas sector, much has changed since January 2008 and the economic slow down will likely result in at least short-term reductions in GHG emissions for Alberta in 2009 and 2010. However, the extent to which this period of reduction will have an effect on the overall projections to 2020 and 2050 remains uncertain.

\section{BRITISH COLUMBIA}

British Columbia is a relatively low GHG emitter compared to other Canadian provinces. With 13 percent of Canada's population and 12.1 percent of Canada's GDP, British Columbia’s GHG emissions accounted for 8.9 percent of Canada's total GHG emissions in $2005 .^{50}$

Transportation represents the largest share of British Columbia GHG emissions, followed by the oil and gas sector. This emission profile is largely due to the extensive use of hydroelectric power and the absence of significant manufacturing.

Government of Alberta, Alberta's 2008 Climate Change Strategy: Responsibility/Leadership/Action (Edmonton: Alberta Environment, 2008) at 23-24, online: Alberta Environment <http://environment.gov.ab.ca/info/library/7894.pdf> [Alberta 2008 Strategy].

47 Statistics Canada, Portrait of the Canadian Population in 2006: Population and Dwelling Counts, 2006 Census, No. 97-550-XIE (Ottawa: Minister of Industry, 2007), online: Statistics Canada <http:// www12.statcan.ca/english/census06/analysis/popdwell/pdf/97-550-XIE2006001.pdf>.

National Inventory 2006, supra note 1 at 584.

Alberta 2008 Strategy, supra note 46 at 7, 15-20, 23-24.

Statistics Canada, "Population by Year, by Province and Territory" Summary Tables, online: Statitstics Canada <http://www40.statcan.ca/101/cst01/demo02-eng.htm>; Statistics Canada, "Gross Domestic Product, Expenditure-based, by Province and Territory" Summary Tables, online: Statistics Canada $<$ http://www40.statcan.ca/ 101/cst01/econ15.htm>. 
GHG emissions grew by 30 percent from 1990 to 2004, with two of the main reasons being population growth (30 percent growth) ${ }^{51}$ and oil and gas activity expansion. ${ }^{52}$ Fossil fuel production accounts for 21 percent of British Columbia GHG emissions with energy demand projected to grow by up to 45 percent in the next 20 years. ${ }^{53}$ To put this in perspective, as an industry, the upstream oil and gas sector accounts for 23 percent of Canada's GHG emissions and 0.5 percent of total global GHG emissions. ${ }^{54}$

British Columbia is one of the lowest GHG emitters in North America on a per capita basis, with emissions of 14.4 tonnes per resident on an annual basis, well below Canada's national average emissions of 22.1 tonnes. ${ }^{55}$ Within Canada specifically, British Columbia ranks third amongst the lowest emitters, with only the Yukon and Quebec having lower per capita emissions. ${ }^{56}$

\section{Climate Change IMPACTS}

\section{ALBERTA}

In contrast to jurisdictions such as Nunavut or the Northwest Territories, where disappearing sea ice provides a tangible reminder of the vulnerability of the region to climate change impacts, much of the focus in Alberta to date has been on identifying mitigation measures designed to limit and eventually decrease provincial GHG emissions rather than on identifying the risks or opportunities that will be created by climate change. However, that is not to suggest that Alberta is immune to the effects of a changing climate.

A study of projected climate change risks and opportunities in the prairies notes that

the most significant threat posed by climate change in the Prairies is the projected increase in climate variability and frequency of extreme events. Climatic extremes, and especially droughts, will limit the opportunities afforded by changing climate and present the greatest challenges for adaptation. ${ }^{57}$

Although the prospect that climate change may result in warmer, shorter winters across the prairies ${ }^{58}$ may be very attractive to most urban Albertans, the attendant changes from an environmental, economic, and social perspective associated with climate change impacts may not be so welcome. Preliminary study suggests that climate change may have unprecedented effects on ecosystems, particularly vulnerable ecosystems such as the boreal forest, and these

BC Stats, British Columbia Population Forecast: Table 1, Summary Statistics (July 2008), online: BC Stats <http://www.bcstats.gov.bc.ca/data/pop/pop/project/bctab1.asp>.

B.C. 's Greenhouse Gas Emissions, online: LiveSmart BC < www.livesmartbc.ca/learn/emissions.html>. BC Climate Action Plan, supra note 25 at 47 (Electricity accounts for 2 percent of total British Columbia GHG emissions. Energy production (electricity and fossil fuel) accounts for 23 percent of British Columbia’s GHG emissions).

Canadian Association of Petroleum Producers, Greenhouse Gas Emissions, online: CAPP <www.capp.ca/environmentCommunity/airClimateChange/Pages/GreenhouseGasEmissions.aspx>. National Inventory 2006, supra note 1 at 23-24, 554.

Ibid. at 535, 555, 566.

Dave Sauchyn \& Suren Kulshreshtha, "Prairies” in Donald S. Lemmen et al., eds., From Impacts to Adaptation: Canada in a Changing Climate 2007 (Ottawa: Natural Resources Canada, 2008) 275 at 319, online: Natural Resources Canada <http://adaptation.nrcan.gc.ca/assess/2007/pdf/full-complet_e.pdf>. Ibid. at 320. 
impacts will in turn affect Alberta's forest, wildlife, and recreational resources. ${ }^{59}$ It may seem obvious that an increase in the extent and severity of flooding will result in significant economic losses and damage to agricultural resources, but commentators are also predicting that flooding can have serious health-related consequences as well. ${ }^{60}$ Warmer, shorter winters in Alberta could also affect the snow pack and hydrological cycles in the Rocky Mountains and this could increase the frequency of landslides, debris flows, and avalanches, affecting public safety, vital transportation corridors, and the pursuit of tourism and recreational opportunities. $^{61}$

Drier and hotter weather is also expected to lead to increases in ambient levels of air pollution (such as ozone and fine particulate) that could have an effect on forests, agriculture, and health and mortality, particularly in the summer months. ${ }^{62}$ Positive effects on agriculture, including increased opportunities arising from longer growing seasons, may be offset by the effects of drought, severity and intensity of storms, and rapid ecosystem shifts. ${ }^{63}$

Additional impacts on the health of Albertans have also been predicted, including increases in and more widespread presence of vector-borne diseases such as hanta virus and West Nile virus, water-borne disease outbreaks associated with flooding, increased survival and extended seasons for food-borne pathogens such as Campylobacter, ${ }^{64}$ and the emergence of diseases previously thought rare or exotic in Canada. ${ }^{65}$

In the Alberta 2008 Strategy the Province expressly recognized that given the range of potential impacts, as well as the existence of huge gaps in the data regarding those potential impacts, "[s]trategies to adapt to climate change must go hand in hand with actions identified in this plan to reduce current and future greenhouse gas emissions. It's not a question of doing one or the other - both approaches are necessary." ${ }^{66}$ Consequently, the Alberta 2008 Strategy contained an express commitment to produce a "Climate Change Adaptation Strategy.” The Adaptation Strategy will "provide overall direction, identify measures and indicators of climate change, provide a source of information about the impacts, and identify risks and vulnerabilities." ${ }^{97}$ Of particular interest to the oil and gas sector is the component of the Adaptation Strategy that focuses on adaptation strategies that need to be adopted to address climate change impacts on energy and municipal infrastructure.

Ibid. at 295.

Ibid. at 319 .

Ibid. at 295, citing Stephan G. Evans \& John J. Clague, "Recent Climatic Change and Catastrophic Geomorphic Processes in Mountain Environments” (1994) 10 Geomorphology 107.

See Cailen Henry, Impacts of Climate Change on Human Health, Discussion Paper C3-08 (Calgary: Climate Change Central, 2002), online: Climate Change Central <http://www.climatechange central.com/files/attachments/DiscussionPapers/Impacts_CC_on_Human_Health.pdf $>$; Serge Lamy \& Véronique Bouchet, “Air Quality, Climate Change and Health” in Jacinthe Séguin, ed., Human Health in a Changing Climate: A Canadian Assessment of Vulnerabilities and Adaptive Capacity (Ottawa: Health Canada, 2008) 113.

Sauchyn \& Kulshreshtha, supra note 57 at 319.

Dominque Charron et al., "The Impacts of Climate Change on Water-, Food-, Vector- and Rodent-Borne Diseases” in Séguin, supra note 62, 171 at 176-77.

Ibid. at 190-91.

Alberta 2008 Strategy, supra note 46 at 21.

Ibid. 


\section{BRITISH COLUMBIA}

There is a strong consensus that British Columbia is already experiencing the effects of climate change with changing temperature patterns, rain patterns (resulting in flooding, erosion, and landslides), and reduced snow pack and glaciers. ${ }^{68}$ Sea levels are anticipated to rise, though the levels of rivers and lakes may decrease. Relatively warmer temperatures have led to an increase in forest fires and insect infestation, including the mountain pine beetle epidemic, which has not only affected the forestry industry and communities reliant on this industry, but also ecosystems themselves. There is also a great deal of uncertainty in predicting climate change impacts, which makes it difficult to make long-range business decisions.

For the British Columbia oil and gas sector, which is primarily based in northeast British Columbia, warmer temperatures will shorten the winter work window for exploration and production. Historically, operations around Fort Nelson and north of Fort St. John have generally been limited to a 12-week work window during the winter months, from midDecember to mid-March. This allows very little impact to soils, easy access, and good construction conditions. However, milder winters have shortened the work window to about eight weeks. This warming may also affect snowfall, resulting in a lack of snow needed for winter roads and reduced water for operations. ${ }^{69}$

In terms of energy demand, a warmer winter in northern British Columbia could result in a decrease in demand for heating fuels, while in southern British Columbia, warmer summers may lead to increased demand for energy to power air conditioning and refrigeration, leading to an increase in the use of coal or natural gas. ${ }^{70}$ As British Columbia's population is concentrated in the south of the province, these effects are not likely to offset each other.

\section{DifFering Legal AND Policy FramewORKS}

\section{A. Climate Change Policy Development}

Although various attempts have been made to implement a federal climate change regime in Canada, this has not yet led to any concrete action. In order to fill this void, and perhaps to anticipate federal action on climate change, provinces have taken steps to implement their own regimes.

\section{Alberta - General Policy FramewOrK}

In Alberta, the pre-Kyoto Protocol era was characterized by calls for harmonization of requirements between the federal and provincial governments and a focus on supporting

$68 \quad$ BC Climate Action Plan, supra note 25 at 7.

69 Brian McBride, "Climate Change in British Columbia and how it may Impact the Upstream Oil and Gas Industry" (Presented to the Adapting to Climate Change in Northern British Columbia Workshop, Prince George, British Columbia, 20 February 2003) 38 at 38-41, online: Canadian Climate Impacts and Adaptation Research Network <http://www.c-ciarn.ca/pdf/climate_change_northern_bc_2003_ proceedings.pdf $>$. 
voluntary initiatives. The Province showed little appetite for establishing emission limits or emissions trading at that time. ${ }^{71}$

In the time leading up to the adoption of the Kyoto Protocol, Alberta lobbied the federal negotiators to ensure the treaty reflected Canada's circumstances (and in particular, Alberta's position as a global energy producer on the rise). ${ }^{72}$ However, when negotiations concluded, the Alberta government was acutely disappointed with the Kyoto Protocol, noting that due to the economic growth that had taken place between 1990 and 1997, the net effect of the targeted 6 percent reduction from 1990 levels would actually be a reduction of more than 25 percent of projected provincial emissions by $2010 .^{73}$ With a developing sense that compliance with the federal commitments under the Kyoto Protocol would be unlikely in a growing Alberta economy, the Province began to work on a strictly Albertan approach to emissions reductions quite distinct from the Kyoto Protocol.

The formative policy work on climate change at that time was conducted by a Cabinet committee on climate change. ${ }^{74}$ The resulting report, Alberta's Strategy for Action on Climate Change, introduced several key concepts that continue to inform Alberta's regulatory process:

- The link between economic development and emissions limits must be recognized, and terms such as "prudent costs" and "best efforts" were contrasted with the mandatory and compliance-oriented language associated with the Kyoto Protocol; and

- $\quad$ There was a notable emphasis on scientific and technological research to find solutions, as well as partnership with industry and government to address energy efficiency and productivity. ${ }^{75}$

In accordance with the Alberta Strategy 1998, work continued on the climate change file through various public/private and regulatory entities while the Province embarked on climate change consultations. In 2000, another concept that underlies Alberta's approach to climate change was introduced: emissions reductions based on intensity (that is, per unit of production) rather than aggregate/total emission caps. ${ }^{76}$ The Province also continued its

71 See e.g. Government of Alberta, News Release, “Alberta Tables Climate Change Action Plan and Progress Report at Environment and Energy Ministers Meeting” (20 November 1995), online: Government of Alberta <http://alberta.ca/acn/199511/3166.html>.

72 Government of Alberta, News Release, 97-151 “Alberta Ministers Continue to Push for Flexible Position in Kyoto” (5 December 1997), online: Government of Alberta <http://alberta.ca/acn/199712/ 5689.html>.

73 Government of Alberta, News Release, “Alberta To Press For Binding Commitment Before Signing On To Kyoto Agreement” (11 December 1997), online: Government of Alberta <http://alberta.ca/acn/ 199712/5712.html>.

74 Alberta's Strategy for Action on Climate Change - Preliminary Report, as appended to Government of Alberta, News Release, “Alberta Releases Strategy for Action on Climate Change” (15 October 1998), online: Government of Alberta <http://www.gov.ab.ca/acn/199810/6865.html > [Alberta Strategy 1998].

75 Ibid.

Government of Alberta, Climate Change Challenge: Alberta Taking Action Now (Edmonton: Government of Alberta, 2000) at 4, online: Alberta Environment <http://environment.gov.ab.ca/ info/library/5903.pdf $>$ [Climate Change Challenge]. 
support for the development of "climate-friendly" technological solutions to reducing emissions, including carbon sequestration and carbon sinks. ${ }^{77}$

In 2002, the Province presented an action plan in Albertans \& Climate Change: A Strategy for Managing Environmental \& Economic Risks that clearly stated that retaining control over the management of Alberta's resources was a central focus of their regulatory agenda. ${ }^{78} \mathrm{By}$ late November 2002, just one month before the Kyoto Protocol was ratified by the federal government, Alberta became the first province to move beyond strategy and action plans to introduce legislation specifically and directly addressing climate change and limits on GHG (or "specified gas" as the proposed legislation referred to it). ${ }^{79}$

For the period from early 2003 through 2007, Alberta's climate change policy focused primarily on more fully developing the legislative framework required for large-scale emitters to measure, report, and ultimately reduce their GHG emissions intensity. Throughout 2007, the Province conducted expert and public consultations that culminated in the introduction of an updated plan and policy, the Alberta 2008 Strategy.

The Alberta 2008 Strategy is based on three central reduction strategies:

- $\quad$ conservation and energy efficiency;

- $\quad$ development and implementation of carbon capture and storage; and

- $\quad$ greening energy production..$^{80}$

These strategies are in keeping with the Province's approach to climate change reductions, but have also started to become a central feature of the overall provincial energy strategy. ${ }^{81}$ As stated in the policy: "Notwithstanding the diversity of views on climate change and its causes, it is clearly in Alberta's and Canada's economic interest to manage its energy future and carbon better. We can build on our strengths, address our challenges and pursue a strategic approach." 82

Consequently, it is anticipated that future regulatory approaches with the potential to result in GHG emissions reductions may be broader in scope and focus than is currently the case.

Ibid. at 5.

Government of Alberta, Albertans \& Climate Change: A Strategy for Managing Environmental \& Economic Risks (Edmonton: Government of Alberta, 2002) at 5-7, online: Alberta Environment <http://environment.gov.ab.ca/info/library/5895.pdf> [Albertans \& Climate Change Strategy].

Bill 32, Climate Change and Emissions Management Act, 2d Sess., 25th Leg., Alberta, 2002.

Alberta 2008 Strategy, supra note 46 at 15-19.

Alberta's Provincial Energy Strategy, supra note 4.

Ibid. at 19 [emphasis in original]. 


\section{Alberta - CARBON CAPTURE AND SEQUESTRATION}

As carbon capture and sequestration (CCS $)^{83}$ is such a central feature of Alberta's GHG reduction policy, and as the fate of future development in Alberta's oil sands is so linked to successful deployment of CCS technology, we have chosen to specifically address CCS policy development in a separate section. The Alberta 2008 Strategy relies on CCS for 70 percent of Alberta's projected GHG emissions reductions by 2050, and it is viewed as essential if the oil and gas sector is to experience economic growth and prosperity while still reducing emissions. ${ }^{84}$ The numbers are staggering, with current estimates indicating that by 2050 Canada could be sequestering $600 \mathrm{Mt}$ of carbon dioxide equivalent $\left(\mathrm{CO}_{2 \mathrm{e}}\right)$ on an annual basis. $^{85}$ The same geological endowment that makes Alberta an energy powerhouse means that it is also ideally situated for the implementation of large-scale CCS due to the close proximity of concentrated carbon dioxide $\left(\mathrm{CO}_{2}\right)$ sources and underground geological formations in the Western Canadian Sedimentary Basin suitable for deep storage. ${ }^{86}$

Alberta's CCS policy is built on a response to several key findings from the National ecoENERGY Carbon Capture and Storage Task Force (CCS Task Force). The CCS Task Force indicated in January 2008 that in the absence of proven integration of CCS technologies of scale, regulatory clarity, and adequate market price signals, solely relying on private financing of projects will not lead to the scale and scope of early project construction required in the short-term. ${ }^{87}$ In response to the CCS Task Force's call to action, Alberta appointed a Carbon Capture and Storage Development Council in April 2008 to produce a plan to guide Alberta's way forward with CCS. ${ }^{88}$ The Province also responded directly to one of the CCS Task Force's urgent requests for a public funding commitment by announcing in July 2008 that Alberta would create a \$2 billion fund to advance CCS initiatives. ${ }^{89}$

At the same time as the funding announcement, the Province also issued a request for expressions of interest for those projects that could be built quickly and result in significant sequestration opportunities (5 Mt by 2015 for all projects). ${ }^{90}$ The stated goal of the program is "to encourage the development of three to five large scale integrated CCS facilities that will capture and permanently store up to five million tonnes of carbon dioxide per year by

83 Carbon dioxide capture and storage (CCS) is the "process whereby $\mathrm{CO}_{2}$ emissions from large industrial facilities are separated from the plant's process or exhaust stream and injected deep underground into secure geologic formations.... CCS involves the capture of high-volume, concentrated streams of $\mathrm{CO}_{2}$ which are then compressed, transported, and disposed of in deep underground geological formations, like those from which oil and gas are produced": see the concept as presented by the ecoENERGY Carbon Capture and Storage Task Force, Canada's Fossil Energy Future: The Way Forward on Carbon Capture and Storage (Calgary: ecoENERGY Carbon Capture and Storage Task Force, 2008) at 2, 4, online: Alberta Energy <http://www.energy.gov.ab.ca/Org/pdfs/Fossil_energy_e.pdf> [CCS Task Force, The Way Forward].

$84 \quad$ Alberta 2008 Strategy, supra note 46 at 17-18.

CCS Task Force, The Way Forward, supra note 83 at v.

Ibid. at vi.

Ibid. at vii.

Government of Alberta, News Release, “Council to help develop Alberta’s path forward on carbon capture” (24 April 2008), online: Government of Alberta <http://alberta.ca/ACN/200804/23372811D 6E8B-ECBD-6A20-0AB89FD6BAF75321.html>.

89 Government of Alberta, News Release, “Alberta surges ahead with climate change action plan” (8 July 2008), online: Government of Alberta <http://alberta.ca/acn/200807/23960039FB54D-CC21-723431C3E853089A1E6C.html> [“Alberta surges ahead”].

90 Ibid.; Government of Alberta, Invitation for an Expression of Interest: Carbon Capture \& Storage Projects in Alberta (Calgary: Alberta Energy, 2008), online: Alberta Energy <http://www.energy.gov. ab.ca/Org/pdfs/CCS_Expression_of_Interest_FINAL.pdf $>$ [CCS EOI Invitation]. 
2015, for a period of at least 10 years. ${ }^{\text {91 }}$ Of the proponents who submitted expressions of interest in September 2008, 20 were invited to submit a full proposal, but as of the deadline of March 31, 2009, only ten of those proponents submitted a total of 11 proposals (one proponent submitted two projects). ${ }^{92}$ Several proponents currently involved in the oil sands, or with plans for future oil sands developments, that had submitted expressions of interest have indicated that in light of the current economic conditions, they would not be submitting full CCS proposals during this process. ${ }^{93}$

Notwithstanding these concerns, at the end of June 2009 three projects were identified as eligible to enter into a letter of intent with the Province for project development. ${ }^{94}$ Two of the proposed sequestration projects will be associated with upgraders in the Industrial Heartland, and the remaining project involves carbon capture associated with an existing coal-fired power generation plant west of Edmonton. According to government estimates, by 2015 the proposed projects will result in GHG emission reductions of approximately 5.5 million tonnes of $\mathrm{CO}_{2}{ }^{95}$

The funding mechanism for these projects has been established under the Carbon Capture and Storage Funding Act, ${ }^{96}$ which received assent on 4 June 2009. Despite the Province's desire to move the successful projects forward irrespective of the current economic climate, it is expected that for the fiscal year March 2009 to March 2010, only \$100 million of the \$2 billion fund will be expended. ${ }^{97}$ According to the Council's recently released Final Report, the $\$ 2$ billion CCS fund is considered a "kick start" only, with the recognition that

[a]lone, it [the \$2 billion CCS fund] will not deliver the government's longer-term CCS and GHG emission reduction goals. Significant additional investment will be required from the federal and provincial governments and industry to further develop the technology and capture additional $\mathrm{CO}_{2}$ over and above the $5 \mathrm{Mt}$ annually sought from the initial wave of funding. In particular, promotion of further CCS projects after the 2015 period will be needed to meet 2020 emission reduction. ${ }^{98}$

In addition to requiring a considerable ongoing financial commitment from the Province to move these types of projects forward, analysis of Alberta's current regulatory regime has identified that significant gaps in the regulatory structure that would govern CCS projects

Alberta Department of Energy, Carbon Capture and Storage Program: Full Project Proposals Information Package (Edmonton: Alberta Energy, 2008) at 4, online: Alberta Energy $<$ http://www.energy.alberta.ca/Org/pdfs/CCS_FPPInfo.pdf> [CCS Storage Program Info. Package]. For a current list of all Full Project Proposals submitted, see online: Alberta Energy <http://www.energy. alberta.ca/Org/pdfs/CCSFPPs.pdf>.

Kelly Cryderman, “Oil giants pull bids for Alberta’s carbon capture funding” Calgary Herald (2 April 2009), online: Calgary Herald <http://www.calgaryherald.com/entertainment/giants+pull+bids+ Alberta+carbon+capture+funding/1455369/story.html $>$. For a list of the proponents and brief summary of the proposals, see Government of Alberta, Information Bulletin, "Government moves forward on carbon capture projects” (30 June 2009), online: Government of Alberta <http://alberta.ca/ACN/200906/2638932A61D80-09C7-C9F7-CCD99F5E0113E39A.html>. Ibid. To convert the press release estimate of $\mathrm{CO}_{2}$ reductions, as expressed by the Province as "onemillion vehicles" being taken off the road into Mt, the authors used the conversion tool available from the U.S. Environmental Protection Agency (EPA), “Greenhouse Gas Equivalencies Calculator,” online: EPA <http://www.epa.gov/cleanenergy/energy-resources/calculator.html>. S.A. 2009, c. C-2.5

Supra note 94.

Alberta Carbon Capture and Storage Development Council, Accelerating Carbon Capture and Storage Implementation in Alberta: Final Report (Edmonton: Alberta Carbon Capture and Storage Development Council, 2009) at 13, online: Alberta Energy <http://www.energy.alberta.ca/Org/pdfs/ CCS_Implementation.pdf> [CCS Development Council Final Report]. 
should be addressed before these projects proceed. The issues include property issues (such as clarification of ownership of disposal rights in split mineral title situations and Crown ownership); regulatory issues (such as expressly authorizing CCS schemes under legislation and establishing environmental assessment requirements); and liability issues (such as remediation liability and liability regimes for third parties).$^{99}$ Indeed, the interim report of Alberta's Carbon Capture and Storage Development Council issued in the fall of 2008 indicated that ongoing work to address these issues would need to be accelerated. However, a review of the regulatory discussion within the Development Council interim report and the final report indicates that existing regulatory structures and approval processes are going to be applied to the initial projects in an effort to bring them forward, with the lessons learned from these initial projects being applied to develop a more fulsome regulatory response in the future. ${ }^{100}$ Although advocating further clarification of the property, regulatory process, and liability issues associated with CCS, the Council's short-term recommendations focus on a "learn-by-doing" approach to the three proposed CCS applications and the development of more robust mechanisms within existing regulatory processes to be "CCS-ready" post$2010 .{ }^{101}$

With so much at stake, determining the best technical, regulatory, environmental, economic, and social path forward is the subject of considerable activity and controversy at present in Alberta. Given the significant extent to which Alberta's future GHG emissions picture is dependent on reductions associated with CCS technology, CCS promises to be a focal point in the provincial GHG emissions regulatory regime going forward.

\section{BRITISH COLUMBIA}

In British Columbia, the 2002 Energy Plan introduced the notion of demand side management measures for long-term planning for regulated electric utilities and measures to encourage conservation of energy. ${ }^{102}$ In 2004, the British Columbia government proposed certain policy actions to reduce GHG emissions through its paper entitled Weather, Climate and the Future: B.C.'s Plan. ${ }^{103}$

In the February 2007 Speech from the Throne, the British Columbia government announced its intention to aggressively deal with climate change through a range of policy and legislative actions including a carbon tax and a cap and trade system to reduce GHG emissions by 33 percent below 2007 levels by 2020. ${ }^{104}$

See the summary of gaps (and suggested solutions) presented in Nigel Bankes, Jenette Poschwatta \& E. Mitchell Shier, “The Legal Framework for Carbon Capture and Storage in Alberta” (2008) 45 Alta. L. Rev. 585 at 629-30.

Alberta Carbon Capture and Storage Development Council, Accelerating Carbon Capture and Storage in Alberta: Interim Report (Edmonton: Alberta Carbon Capture and Storage Secretariat, 2008), online: Alberta Energy <http://www.energy.alberta.ca/Org/pdfs/CCSInterimRept.pdf>; CCS Development Council Final Report, supra note 98. CCS Development Council Final Report, ibid. at 49-55. Government of British Columbia, Energy for Our Future: A Plan for BC (Victoria: Ministry of Energy and Mines, 2002) at 8-11. 
This was followed later that same month with the 2007 BC Energy Plan ${ }^{105}$ with its goals of reducing GHG emissions, encouraging the use of alternative energy sources (including geothermal, solar, wind, and bioenergy) and creating energy self-sufficiency for British Columbia by 2016. The BC Energy Plan set targets of zero emissions from coal-fired electricity generation and zero net GHG emissions for all existing thermal electricity power plants by 2016. In addition, 90 percent of new energy generation is to be from renewable electricity generation and 50 percent of increased energy demand is to be achieved by conservation. ${ }^{106}$ The plan also set a goal of a 5 percent renewable fuel component for diesel and gasoline by $2010 .^{107}$

The BC Energy Plan recognized the importance of the oil and gas sector to British Columbia, and with declining production elsewhere in the world, British Columbia saw an opportunity to stimulate development in new basins such as the Nachako Basin, the development of unconventional resources such as tight gas, shale gas, and coalbed gas, and to even work to lift the moratorium on offshore oil and gas development. ${ }^{108}$

The BC Energy Plan identified the main sources of GHG emissions from the oil and gas sector as coming from flaring, fugitive gases, gas processing, and compressor stations. ${ }^{109}$ The British Columbia government committed to eliminating all routine flaring at oil and gas producing wells and production facilities by 2016 with an interim goal to reduce flaring by 50 percent by 2011. In addition, the government proposed new policies to reduce natural gas flaring and venting at test sites and pipelines and to encourage compressor station efficiencies in order to reduce GHG emissions. ${ }^{110}$ As a mitigation measure for GHG emissions, the BC Energy Plan committed the government to advancing carbon capture and storage. ${ }^{111}$

The BC Energy Plan also committed the government to energy efficiency by building on such programs as the Energy Efficient Buildings: A Plan for BC, ${ }^{112}$ the Community Action on Energy Efficiency program, the Green Buildings BC Program, and the Energy Efficient Buildings Strategy. In the future, the British Columbia government intends to address industrial sector energy efficiency through the Industrial Energy Efficiency Program to be implemented by $2010 .^{113}$

The British Columbia government also committed to funding technologies to support renewable energy and GHG reductions through the Innovative Clean Energy Fund. In July 2008, the British Columbia government announced 15 projects that received a total of \$25 million, including one project for $\mathrm{CO}_{2}$ recovery. ${ }^{114}$

\footnotetext{
105 Supra note 21.

$106 \quad$ Ibid. at 5, 13.

107 Implemented through the Greenhouse Gas Reduction (Renewable and Low Carbon Fuel Requirements) Act, S.B.C. 2008, c. 16

108 BC Energy Plan, supra note 21 at 29. The plan also calls for British Columbia to consider a Net Profit Royalty Program (at 33).

Ibid. at 30 .

Ibid. at 31.

Ibid. at 30-31.

Government of British Columbia, Energy Efficient Buildings: A Plan for BC (Victoria: Government of British Columbia, 2005).

BC Energy Plan, supra note 21 at 7-8.

Ibid. at 17.
} 
In April 2007, British Columbia became the first Canadian province to join the Western Climate Initiative (WCI), which is focused on implementing a regional cap and trade system to reduce GHG emissions. The WCI was formed in February 2007 by the states of Arizona, California, New Mexico, Oregon, and Washington. The WCI aims to implement a marketbased cap and trade system that will set hard limits (or caps) on GHG emissions and then allow the market to identify the most cost-effective way to achieve this. Each WCI jurisdiction will have an emission allowance budget and each member jurisdiction will decide how to best allocate its allowance budget within its own jurisdiction, including auctioning a certain percentage of the allowances. ${ }^{115}$

In June 2008, the government released the BC Climate Action Plan, which elaborated on the Throne Speech promises and set out how phase one of the plan would be implemented in relation to specific sectors of the economy. ${ }^{116}$ The BC Climate Action Plan confirmed that the carbon tax and cap and trade program are key features of British Columbia's strategy to tackle climate change, and also announced motor vehicle fuel efficiency standards, alternative fuels, the Innovative Clean Energy fund to subsidize renewable energy projects, a \$25 million fund for the Bioenergy Strategy, and a plan for energy production from wood damaged by the mountain pine beetle. ${ }^{117}$ In relation to the energy sector, the Plan noted the elements of the BC Energy Plan, emphasized conservation as an important component of reducing GHG emissions, and noted the Remote Community Clean Energy Program (which provides financial incentives to communities to switch from diesel power to cleaner sources and energy conservation). ${ }^{118}$

\section{B. CURRENT LEgISLATIVE INITIATIVES}

\section{ALBERTA}

\section{a. The Constitutional Context}

Although there has been, ${ }^{119}$ and continues to be, much discussion regarding the constitutional basis for Alberta's regulatory approach to limiting GHG emissions, detailed analysis of these complex questions is beyond the scope of this article. However, when reviewing Alberta's regulatory response to limiting GHG emissions, it is important to be cognizant of the constitutional context that gave rise to the legislation.

One fairly constant theme underlying Alberta's regulatory regime is the view that any attempt at federal GHG regulation usurps the province's constitutional jurisdiction over natural resources and property and civil rights. ${ }^{120}$ This view was emphasized in the discussion accompanying the introduction of the provincial legislation in 2002: “Our Climate Change

For the most up-to-date membership, requirements, and initiatives of the Western Climate Initiative, see online: Western Climate Initiative <http://www.westernclimateinitiative.org/>.

BC Climate Action Plan, supra note 25 at 12.

Ibid. at 66-68.

Ibid. at 48.

See e.g. Nigel D. Bankes \& Alastair R. Lucas, "Kyoto, Constitutional Law and Alberta’s Proposals" (2004) 42 Alta. L. Rev. 355.

120 Constitution Act, 1867 (U.K.), 30 \& 31 Vict., c. 3, ss. 92(13), 92A, reprinted in R.S.C. 1985, App. II, No. 5. 
and Emissions Management Act reaffirms Alberta’s ownership and responsibility for the management and development of its natural resources."121

As clearly stated in the Preamble to the provincial legislation, the scope of the provincial climate change legislation is founded on, and is inextricably linked to the provincial control over natural resource development:

WHEREAS the Government of Alberta owns natural resources in Alberta on behalf of all Albertans and manages the exploration, development and production of renewable and non-renewable resources in Alberta;

WHEREAS atmospheric carbon dioxide and methane are not toxic and are inextricably linked with the management of renewable and non-renewable natural resources, including sinks. ${ }^{122}$

Although we have not yet seen a constitutional challenge to the provincial legislation or the introduction of a paramount federal regulatory regime, the potential for a constitutional showdown over jurisdiction remains. However, until challenged, the net effect of these constitutional strictures is that Alberta's regulatory regime reflects a narrowed scope of emissions regulation that does not incorporate international commitments such as the Kyoto Protocol, that does not recognize offsets or carbon trading mechanisms beyond Alberta's borders, and that primarily applies to emitters in the natural resources sectors. As a result, the narrow "made in" and "made exclusively for Alberta” legislative approach to emissions reductions that developed to reflect Alberta's view of these constitutional bounds is likely to pose an obstacle to current federal and international GHG emissions reduction harmonization initiatives.

\section{b. $\quad$ Large Scale Emitters GHG Intensity Limits and Reporting}

In Alberta, provincial emissions reduction requirements are derived from the framework for defining, reporting, and ultimately reducing "specified gases"123 established under the Climate Change and Emissions Management Act. ${ }^{124}$

The CCEMA enshrines several of the policies specific to Alberta that were introduced in the climate change strategies and action plans developed in the 1990s. In contrast to the approaches in other jurisdictions, the emissions reduction targets enacted under s. 3 of the CCEMA are linked directly to Alberta's GDP. Consequently, the targets established are "intensity" 125 based and do not provide an aggregate or total cap on emissions. Although s.

Legislative Assembly, Alberta Hansard (19 November 2002) at 1377 (The Honourable Ralph Klein, then Premier of Alberta, discussing the introduction of Alberta's Climate Change and Emissions Management Act, S.A. 2003, c. C-16.7 [CCEMA]).

122 CCEMA, ibid., Preamble.

123 Ibid., s. 1(g). "Specified gas" is defined to mean “any gas that traps heat near the earth's surface and includes without limitation, carbon dioxide, methane, nitrous oxide, hydrofluorocarbons, perfluorocarbons and sulphur hexafluoride." Ibid.

The Specified Gas Emitters Regulation, Alta. Reg. 139/2007, s. 1(1)(h) [Emitters Regulation] defines "emissions intensity" to mean "the quantity of specified gases released by a facility per unit of production from that facility.” 
3 of the CCEMA mandates that emissions intensity must be reduced by 50 percent over 1990 levels by 31 December 2020, with economic growth, the Province's total emissions may continue to climb even though emissions intensity drops by half. ${ }^{126}$

A central facet of the CCEMA was the establishment of mandatory reporting requirements for emitters that release an amount exceeding the threshold value established by regulation. ${ }^{127}$ From 2004 to 2007, the primary responsibility for this category of emitters was filing their annual report of emissions under the Specified Gas Reporting Regulation. ${ }^{128}$ Ultimately, these reports (2003-2006) provided the baseline for the emissions reduction targets adopted under amendments to CCEMA in 2007.

In terms of the scope of the CCEMA, with the threshold for reporting set at 100,000 tonnes of $\mathrm{CO}_{2 \mathrm{e}}$ : in 2004 there were 98 facilities required to report; in 2005 there were 101 facilities required to report; ${ }^{129}$ in 2006 there were 103 facilities required to report; $;{ }^{130}$ and in 2007 there were 106 facilities required to report. ${ }^{131}$ Approximately half of the companies required to report under the CCEMA regime are in the oil and gas sector. ${ }^{132}$ The statistics from the reporting period in 2004 indicated this threshold value captured total reported emissions of $109 \mathrm{Mt}$ and this accounted for 47 percent of Alberta's total GHG emissions and 64 percent of all industrial GHG emissions in the Province. ${ }^{133}$ Clearly, a change to the reporting threshold has the potential to significantly impact CCEMA's scope, relevance, and the extent to which reductions occur. ${ }^{134}$

As one would expect from the title, the Reporting Regulation provides key regulatory details regarding the reporting regime. ${ }^{135}$ Additional technical details of the reporting regime

In January 2008, the Province predicted that at the prevailing growth rates the Province's total emissions by 2020 - even assuming mitigation measures reduced intensity - would still be 1.5 times greater than 1990 levels: see Alberta 2008 Strategy, supra note 46 at 23-24. Although a contracting economy is now predicted for 2009 and possibly into 2010, how much this will reduce emissions is unclear. The reporting threshold is currently at 100,000 tonnes of $\mathrm{CO}_{2 \mathrm{e}}$ : see Specified Gas Reporting Regulation, Alta. Reg. 251/2004, s. 2 [Reporting Regulation] (incorporating, by reference, the threshold set in Alberta Environment, Specified Gas Reporting Standard (Edmonton: Alberta Environment, 2009), s. 2(1), online: Alberta Environment <http://environment.alberta.ca/documents/ghg_specified_ gas_reporting_standard.pdf> [Reporting Standard]). Reporting Regulation, ibid.

Alberta Environment, Summary Report on 2005 Greenhouse Gas Emissions (Edmonton: Alberta Environment, 2007) at 12, online: Alberta Environment <http://environment.gov.ab.ca/info/library/ 7757.pdf $>$ [AB GHG Summary Report 2005].

130 Alberta Environment, Report on 2006 Greenhouse Gas Emissions (Edmonton: Alberta Environment, 2007) at iii, online: Alberta Environment <http://environment.alberta.ca/documents/2006_GHG_ Report.pdf> [AENV 2006 Report on GHG Emissions].

131 Alberta Environment, Report on 2007 Greenhouse Gas Emissions (Edmonton: Alberta Environment, 2008) at iv, online: Alberta Environment < http://environment.alberta.ca/documents/2007_GHG_Report. pdf $>$.

132 For the purposes of this section of the article, we have included conventional oil and gas, refining, pipelines, and oil sands developments in this category.

133 AB GHG Summary Report 2005, supra note 129 at 19-20.

134 In 2008, in the Alberta 2008 Strategy, supra note 46 at 16, it was suggested that the threshold value for reporting (although perhaps not emissions intensity reductions) may be shifting downward from 100,000 tonnes to 50,000 tonnes of $\mathrm{CO}_{2 \mathrm{e}}$ in the near future, but this has not yet happened. It has been suggested that a threshold set at 50,000 tonnes would quadruple the number of emitters governed by the Reporting Regulation, supra note 127. to report: see Reporting Regulation, ibid., ss. 2-4, 9; Reporting Standard, supra note 127, ss. 2-6; CCEMA, supra note 121, s. 6. 
are contained in the Specified Gas Reporting Standard, a technical standard that is incorporated by reference into the Reporting Regulation. ${ }^{136}$

In 2007, after three years of reporting under the CCEMA regime, the Act was significantly amended to implement the Province's plan for reductions by establishing intensity reduction targets for emitters exceeding the 100,000 tonne reporting requirement through the Climate Change and Emissions Management Amendment Act, 2007, ${ }^{137}$ and associated Specified Gas Emitters Regulation. ${ }^{138}$ The CCEMAA and the Emitters Regulation were proclaimed in force on 20 April 2007, and the reduction targets prescribed in the legislation took effect on 1 July 2007.

The amendments introduced under the CCEMAA and the Emitters Regulation were significant to all emitters governed by the CCEMA because the amendments established intensity reduction limits on both existing facilities and new facilities. The Emitters Regulation established the requirement that an established facility (as defined under s. 1(l)(i)) must reduce their emissions intensity by 12 percent from "baseline emissions intensity" (the average of the facility's 2003-2005 emissions intensity) on or before 1 July 2007. To reflect that newer facilities are expected to have better efficiency, there was a six-year phase-in of emissions intensity reductions of 2 percent per year until a reduction of 12 percent of the baseline intensity (established in the first three years of operation) is reached. ${ }^{139}$

\section{c. Mechanisms for Meeting GHG Intensity Limits, Including Offsets,} Fund Levies, and Credits

The compliance and enforcement mechanisms established under the CCEMAA and Emitters Regulation illustrate the "carrot and stick" approach to emissions reductions. The framework prescribes that if a facility cannot meet the net emissions intensity limit applicable to their operations by directly reducing their GHG emissions intensity, three other compliance options are available. ${ }^{140}$

First, emissions offsets ${ }^{141}$ could be purchased from facilities located in Alberta that are not governed by the emissions intensity limits under the Emitters Regulation, but nonetheless have reduced their specified gas emissions. To be eligible, the specific conditions itemized in s. 7 of the Emitters Regulation must be met, so that the emissions must:

- “occur in Alberta”;

• “occur on or after January 1, 2002”;

The Reporting Standard prescribes important technical requirements such as establishing the specified gas reporting threshold; the emission information that must be supplied; and providing guidance on acceptable emission calculation methods: see Reporting Regulation, ibid., s. 2; Reporting Standard, ibid., ss. 2, 5, 7; CCEMA, ibid.

137 S.A. 2007, c. 4 [CCEMAA]

$138 \quad$ Emitters Regulation, supra note 125

139 Ibid., ss. 1-4.

140 Ibid., ss. 7-9.

141 Defined as "a reduction in the release of specified gases, expressed on a tonnes of $\mathrm{CO}_{2 \mathrm{e}}$ basis, that meets the requirements of section 7(1)": see ibid., s. 1(1)(f). 
- $\quad$ "be real and demonstrable";

- “quantifiable and measurable”; and

- "result from an action taken that is not otherwise required by law."142

In contrast to the design of other offset systems, ${ }^{143}$ the structure of Alberta's offset system does not contemplate integration with interprovincial, national, or international emissions trading systems. Consequently, the extent to which the Alberta trading scheme can be incorporated into or harmonized with the proposed federal offset trading system remains unclear. ${ }^{144}$

The framework for establishing credible offsets was rolled out in the fall of 2007 (after the initial compliance period had commenced) with the introduction of quantification protocols, ${ }^{145}$ a guidance document, and a verification standard. ${ }^{146}$ As was predicted by commentators reviewing the early legislative base that created carbon sinks, several issues limited the use of these offsets in the first compliance period, including the following:

- $\quad$ a lack of liquidity;

- $\quad$ limited transparency;

- $\quad$ a lack of clear price signals;

- $\quad$ concerns regarding cost, completeness, and credibility of verification, and availability of third party auditors;

- $\quad$ integration (or lack thereof) between federal and provincial systems;

- $\quad$ a lack of standardization of contracts;

- $\quad$ unresolved liability concerns; and

$142 \quad$ Ibid., s. 7(1).

143 Such as the British Columbia credit system established under their cap and trade legislation, also outlined in this article.

144 See Environment Canada, Turning the Corner: Canada's Offset System for Greenhouse Gases (Ottawa: Environment Canada, 2008), online: Environment Canada <http://www.ec.gc.ca/doc/virage-corner/ 2008-03/526_eng.htm>.

145 The first set of quantification protocols focused heavily on agricultural offsets, including beef feeding, beef life cycle, pork production, and tillage. However of particular interest to the oil and gas sector were the protocols for quantification of offsets associated with biofuel, biogas, biomass, energy efficiency, enhanced oil recovery, and waste heat recovery. For a current listing of the approved protocols and copies of the detailed protocols and quantification methods, see "Approved Alberta Protocols,” online: Carbon Offset Solutions <http://www.carbonoffsetsolutions.ca/offsetprotocols/finalAB.html>.

146 To ensure that the offset credits under this framework were of sufficient quality and credibility to be used for compliance purposes, the Province introduced a verification guidance document to assist both buyers and sellers of offsets to understand the approach to verification that has been adopted by the Province: see Alberta Environment, Offset Credit Verification Guidance Document (Edmonton: Alberta Environment, 2007), online: Alberta Environment <http://www3.gov.ab.ca/env/climate/docs/ Verification_Document_Alberta_Offsets.pdf $>$. 
- $\quad$ the Province’s reticence to establish dispute resolution mechanisms. ${ }^{147}$

The second compliance mechanism permitted under the CCEMA consists of the purchase of "fund credits," which are obtained by paying $\$ 15$ per tonne of $\mathrm{CO}_{2 \mathrm{e}}$ to the Climate Change and Emissions Management Fund (CCEM Fund) to receive a reduction credit. ${ }^{148}$ Perhaps reflecting some of the limitations of the offset system, payment into the CCEM Fund is currently the most popular compliance option. Alberta Environment had originally estimated that the payments into the CCEM Fund by Alberta's top 100 emitters could be up to $\$ 177$ million annually, ${ }^{149}$ but for the first compliance period (a six-month period) $\$ 40$ million was paid into the CCEM Fund in April 2008, ${ }^{150}$ and $\$ 82.3$ million was paid into the CCEM Fund for the second compliance period (the first full year compliance period) in April 2009. ${ }^{151}$

The third compliance mechanism established under the Emitters Regulation is the purchase of "emission performance credits" from facilities that have emissions intensity limits under the legislation, but whose actual emissions intensity is below their emissions intensity limit for that period. ${ }^{152}$

All three compliance mechanisms: emissions offsets, fund credits, and emission performance credits, constitute revocable licences that authorize the person responsible to emit the quantity of specified gas represented by the licence. ${ }^{153}$

In the first compliance period under the CCEMA (July 2007 to December 2007), carbon offsets arising from wind projects, aggregated agricultural offsets, and landfill gas capture accounted for approximately $1 \mathrm{Mt}$ of the total reductions required for large-scale emitters to meet the emissions intensity targets in $2007 .{ }^{154}$ In 2008, for the first full year of compliance under the CCEMA (January 2008 to December 2008), carbon offset purchases rose, accounting for approximately $2.75 \mathrm{Mt}$ of the total reductions required for large-scale emitters to meet their emissions intensity targets in $2008 .{ }^{155}$

See the prediction that these issues may limit the use of offsets in the context of agricultural offsets in Steven A. Kennett \& Alastair R. Lucas, "Transaction Costs and Other Issues for Carbon Sequestration on Agricultural Land: Defining the Legal and Policy Agenda” (2004) 14 J. Envtl. L. \& Prac. 47 at 71-72. For a discussion of these issues moving beyond the hypothetical and now into the context of the current offset regime, see the discussions in Larry Ruud et al., Alberta Offset System - First Year Retrospective (Leduc: Alberta Environment, 2008) at 4-5, online: Carbon Offset Solutions <http:// www.carbonoffsetsolutions.ca/pdf/july32008_consultation/July\%203\%20Discussion\%20Paper\%20( final).pdf $>$.

Emitters Regulation, supra note 125, ss. 1(1)(k), 1(1)(1), 8.

See the estimates in Alberta Environment, Meeting the Challenge: SGER Compliance System and Reporting Form Information Session (Edmonton: Alberta Environment, 2007) at 12, online: Alberta Environment <http://www.environment.alberta.ca/documents/SGER_Compliance_Workshop_ Presentation.pdf $>$.

Government of Alberta, News Release, "Alberta industries comply with pivotal climate change legislation” (30 April 2008), online: Government of Alberta <http://alberta.ca/acn/200804/ 23421A13065 B8-02F7-B8BB-28C7FACB086E54EE.html> [“Alberta industries comply, 2008”].

Government of Alberta, News Release, “Alberta Realizes 6.5 million tonnes of GHG Reductions” (22 April 2009), online: Government of Alberta <http://alberta.ca/acn/200904/25761CEE17478-A430B24A-B65903CB1372560F.html>.

Emitters Regulation, supra note 125, ss. 1(1)(g), 9.

Ibid., s. 10.

See Alberta Environment, Specified Gas Emitters Program - Review Workshop (Edmonton: Alberta Environment, 2008) at 4, online: Carbon Offset Solutions <http://www.carbonoffsetsolutions.ca/ pdf/July32008_consultation/SGER\%20\%20Post\%20Mortem-June\%202008.pdf> [Specified Gas Emitters Program Review 2008]; “2007 Greenhouse Gas Emission Reduction Program Results,” online: Alberta Environment <http://environment.alberta.ca/3317.html> [“2007 GHG Reduction Results”].

“Alberta Realizes 6.5 million tonnes of GHG Reductions,” supra note 151. 
In both 2007 and 2008, by far, the most popular compliance mechanism was payment into the CCEM Fund, resulting in total payments of \$40 million into the CCEM Fund in 2007, ${ }^{156}$ with a total of 55 facilities of the 93 providing compliance reports choosing this form of compliance. ${ }^{157}$ Similarly, in 2008, companies paid $\$ 82.3$ million into the CCEM Fund. ${ }^{158}$

With respect to the third compliance mechanism, emissions performance credits, only 34 facilities used this form of compliance in 2007, accounting for approximately $1 \mathrm{Mt}$ of the total required reductions. ${ }^{159}$ A review of these credits in 2008 suggested that many of the emission performance credits claimed occurred as a result of facilities engaging in cogeneration initiatives, rather than as a result of facilities improving their own emissions intensity. Consequently, the Province embarked upon a review of this use of emissions performance credits to ensure that its use still achieved the objective of emissions reduction originally envisioned by the Act. ${ }^{160}$ In 2008, $1.29 \mathrm{Mt}$ of the total required emissions reductions were based on emission performance credits generated by regulated facilities. ${ }^{161}$

In summary, the two reporting periods indicate that when offsets, facility improvements, and emissions performance credits are taken into account, the emissions reduction targets established under the CCEMA resulted in the actual reduction of $3.7 \mathrm{Mt}$ of $\mathrm{CO}_{2}$ emissions in 2007 and $6.53 \mathrm{Mt}$ of $\mathrm{CO}_{2}$ emissions in 2008. ${ }^{162}$ Based on the payment of $\$ 122.3$ million in the CCEM Fund, a further $8.2 \mathrm{Mt}$ of reductions is still required to meet the intensity targets of facilities currently regulated under the CCEMA.

\section{d. Enforcement under the Current Emissions Reduction Regime}

In addition to the "carrot" of compliance mechanisms, the Province's current regime also includes significant "sticks" in terms of offences and penalties under both the provisions of the CCEMA and Emitters Regulation. For example, failure to comply with emissions intensity limits is an offence under the Emitters Regulation (subject to the due diligence defence), and offenders may face a penalty of not more than $\$ 200$ for every tonne of specified gases emitted that exceeds the emissions intensity limit. ${ }^{163}$ The Emitters Regulation also prescribes other offences that are unique to the GHG reporting regime, such as failing to submit compliance reports, establish baseline intensity, retain a qualified third party

156 “Alberta industries comply, 2008,” supra note 150. In November 2008, the CCEMA, supra note 121, provisions governing the CCEM Fund were amended by the CCEMAA, supra note 137, to allow the Minister to establish a delegated authority that will administer the CCEM Fund. Thus, the Minister can segregate the CCEM Fund from the Province's general revenue and then disburse from the CCEM Fund in the form of a yearly grant to the arm's-length group appointed by the Minister to manage and administer it. Although accountable to the Auditor General, the fund management group will act independently to invest the fund in areas such as: energy conservation and efficiency; demonstration projects and projects using new technologies to reduce GHGs (e.g. CCS); the development of carbon offset projects; and investment in climate change adaptation programs: see Government of Alberta, News Release, "Legislation launches climate change fund as vehicle to deliver real emission reductions" (30 April 2008), online: Government of Alberta <http://alberta.ca/acn/200804/ 23419A1030535-DBAD651B-8FB5E6FBDB74469C.html>.

“2007 GHG Reduction Results,” supra note 154.

“Alberta Realizes 6.5 million tonnes of GHG Reductions,” supra note 151.

Specified Gas Emitters Program Review 2008, supra note 154 at 4-5.

Ibid. at 8.

“Alberta Realizes 6.5 million tonnes of GHG Reductions,” supra note 151.

Ibid.

Emitters Regulation, supra note 125, ss. 27-29. 
auditor, and the like. ${ }^{164}$ The CCEMA also includes offence provisions that are not as specifically linked to GHG emissions reductions and are more analogous to the general offences contained in environmental legislation, such as failing to provide information required under the Act or regulations, supplying false or misleading information, contravening a compliance order, failing to assist an inspector, or interfering with an inspector. $^{165}$

With respect to enforcement tools, the Emitters Regulation specifically authorizes investigations, inspections, and audits associated with any of the obligations. ${ }^{166}$ Further, where a party exceeds the emissions intensity limit or is found to have miscalculated emissions intensity, the Director may make an order requiring the person responsible to undertake measures to minimize or remedy the breach. ${ }^{167}$ It is important to note that even if a person responsible for compliance has been charged with or convicted of an offence or has been required to pay an administrative penalty in relation to the circumstances that gave rise to the order, a Director may still issue an order to take measures to remedy the breach. ${ }^{168}$ The Director's order powers are broad and include the power to direct the person responsible under the order to obtain emissions or performance credits, make contributions to the CCEM Fund, and/or take any other measures advisable. ${ }^{169}$

Also paralleling the Emitters Regulation, the CCEMA gives broad investigation, inspection, search, and seizure powers to investigators and inspectors under the Act. ${ }^{170}$ CCEMA also includes broad order-making powers for Directors to issue a compliance order, and/or issue an administrative penalty when it is his or her opinion that a person has contravened the Act or the regulations. ${ }^{171}$ Paralleling the offences and penalties framework established under the Environmental Protection and Enhancement Act, ${ }^{172}$ the "knowing" offences under the CCEMA, such as knowingly contravening a compliance order or knowingly providing false or misleading information pursuant to a requirement under the $A c t$ or regulations, are the most significant offences, subject to more significant punishment. ${ }^{173}$ The CCEMA enforcement framework further supports more stringent treatment of offenders who "knowingly" commit an offence by providing that the due diligence defence is available for all offences except those that are done knowingly. ${ }^{174}$

Ibid. (the penalty for these offences is a fine of up to $\$ 50,000$ for an individual and up to $\$ 500,000$ for a corporation, and due diligence is a defence to these offences as well); CCEMA, supra note 121, s. 29. CCEMA, ibid., ss. 44-45. Just as in the Emitters Regulation provisions, the penalty for these offences is a fine of up to $\$ 50,000$ for an individual and up to $\$ 500,000$ for a corporation.

Emitters Regulation, supra note 125, s. 25.

Ibid., s. 26.

Ibid., s. 26(4).

Ibid., s. 26(2).

CCEMA, supra note 121 , ss. $13-28$.

Ibid., ss. 29, 38; Administrative Penalty Regulation, Alta. Reg. 140/2007. The regulations referred to in this section include the Specified Gas Reporting Regulation, supra note 127, the Emitters Regulation, supra note 125, and the Reporting Standard, supra note 127.

R.S.A. 2000, c. E-12.

CCEMA, supra note 121, ss. 44-45. An offender under this category of offences may be subject to a fine of up to $\$ 100,000$ and/or imprisonment for up to two years for an individual, and a fine of up to $\$ 1,000,000$ for a corporation (double the penalty of the category of offences that are not conducted with knowledge).

Ibid., ss. 44(a)-(d), 46. 
In addition to the fines levied under the Act, the CCEMA also has a profit stripping mechanism that allows an additional fine to be imposed in the amount of any benefit accruing to the person responsible as a result of a breach of the Act or regulations. ${ }^{175}$ As is the case in most environmental legislation, directors, officers, or agents of a corporation who direct, authorize, assent to, acquiesce in, or otherwise participate in an offence may be found guilty of an offence themselves, irrespective of whether the corporation is ultimately charged. ${ }^{176}$ Also paralleling Alberta's general environmental legislation, the CCEMA includes a mechanism for two or more adult members of the public who suspect that a breach of the Act or regulations has occurred to trigger an investigation. ${ }^{177}$

\section{e. $\quad$ Renewable Fuels Standard}

In order to meet the emission reduction goals established under the Alberta 2008 Strategy that are associated with conservation and energy efficiency, the Province intends to introduce a Renewable Fuels Standard. This Standard is likely to parallel the federal renewable fuels standard by requiring 5 percent renewable content ${ }^{178}$ in gasoline by July 2010 and 2 percent renewable content in diesel and heating oil by 2012. ${ }^{179}$

\section{BRITISH COLUMBIA}

\section{a. GHG Emission Reduction Targets Enshrined in Law}

A key element of British Columbia's plan to deal with climate change is to reduce GHG emissions by 33 percent below 2007 levels by 2020, which has been enshrined in law through the Greenhouse Gas Reduction Targets Act, ${ }^{180}$ which came into operation on 1 January 2008. Greenhouse gases are defined to include "carbon dioxide, methane, nitrous oxide, hydrofluorocarbons, perfluorocarbons, sulphur hexafluoride and any other substance prescribed by regulation." "181 The target is that by 2020 and for each subsequent year, British Columbia GHG emissions will be at least 33 percent less than the level of those emissions in 2007. ${ }^{182}$ By 2050 and in each subsequent year, the target for GHG emissions will be 80 percent less than 2007 levels. ${ }^{183}$ The Act also sets out interim targets for reductions. Reductions have been set at 6 percent below 2007 levels for 2012, and 18 percent below

Ibid., s. 47.

Ibid., s. 49.

Ibid., s. 11.

The Province indicates that "renewable fuels" are those made from biological sources such as grain, canola, corn, cellulose from plant fibres, switch grass, straw, or forestry and livestock waste products. Specific examples provided in the fact sheet accompanying the announcement of the Standard are ethanol and biodiesel: see Government of Alberta, Talk about Bioenergy (April 2009), online: Alberta Energy <http://www.energy.gov.ab.ca/BioEnergy/pdfs/FactSheet_RFS.pdf > . Ibid.

S.B.C. 2007, c. 42 [Reduction Targets Act].

Ibid., s. 1 .

Ibid., s. 2(1)(a).

Ibid., s. 2(1)(b). 
2007 levels for $2018 .^{184}$ The Minister is required to report on the annual GHG emissions and the progress towards meeting the targeted reductions.

\section{b. Government to Become Carbon Neutral by 2010}

The British Columbia government has also set targets for reductions in GHG emissions for the public sector, requiring public sector organizations to be carbon neutral by 2010, and as an interim target, to be carbon neutral for government travel for the 2008 and 2009 calendar years. ${ }^{185}$ It is anticipated that the public sector will have to buy carbon credits to achieve carbon neutrality, with the Pacific Carbon Trust, a Crown corporation, set up specifically to manage emission offsets. ${ }^{186}$ The Emission Offsets Regulation ${ }^{187}$ sets out the process for validating and verifying reductions of GHG emissions as well as determining which actions or projects will be recognized as emission offsets.

\section{c. $\quad$ Cap and Trade System}

The WCI anticipates a region-wide cap and trade system, which will set hard caps (or limits) on the GHG emissions for each member jurisdiction. British Columbia has implemented a framework to participate in the WCI cap and trade system in the Greenhouse Gas Reduction (Cap and Trade) Act. ${ }^{188}$ Specifically, the British Columbia government will establish caps for designated large GHG emitters by issuing tradeable compliance units that correspond to specific periods of time. Each emitter will be required to surrender to the government the number of compliance units equal to the amount of GHG emissions from its operations. A compliance unit is equal to one tonne of $\mathrm{CO}_{2}$ or its equivalent. Failure to do so and to report is subject to penalties.

There are three types of compliance units. First, the BC Allowance Unit (BCAU) is a unit issued by the British Columbia government according to the caps specified in a given compliance period. ${ }^{189}$ Second, BC Emission Reduction Units (BCERU) are offset credits from approved emission reduction or removal projects in British Columbia. ${ }^{190}$ Third, Recognized Compliance Units (RCU) are those units from other cap and trade systems that are recognized by the British Columbia system. It is anticipated that the RCU will include those units established by the WCI cap and trade system. ${ }^{191}$ Operators must submit compliance reports and there are a range of compliance and enforcement tools including administrative and other penalties, directions, and citizen participation in enforcement. ${ }^{192}$

“2012 \& 2016 Interim Targets,” online: LiveSmart BC <http://www.livesmartbc.ca/government/ interim_targets.html>. In August 2008, the Climate Action Team provided its recommended interim targets for 2012 and 2016: by 2012, the growth in emissions must be reversed and emissions must begin to decline significantly, to between 5 and 7 percent below 2007 levels. These reports are open for public comment prior to the interim targets being set. However, as required by the Reduction Targets Act, supra note 180, s. 2(2), the interim targets for 2012 and 2016 will be set into law through regulation. Reduction Targets Act, ibid., s. 5.

See Carbon Neutral Government Regulation, B.C. Reg. 392/2008.

B.C. Reg. 393/2008.

S.B.C. 2008, c. 32 [GHG Cap and Trade Act].

Ibid., ss. 1, 6. See also Government of British Columbia, News Release, 2008ENV0035-000462, "B.C. First Province to Legislate Cap and Trade” (3 April 2008), online: Government of British Columbia <http://www2.news.gov.bc.ca/news_releases_2005-2009/2008ENV0035-000 462.htm>.

GHG Cap and Trade Act, ibid., ss. 1, 8.

Ibid., ss. $1,11$.

Ibid., ss. 17, 23, 32. 
British Columbia recently introduced the Reporting Regulation, ${ }^{193}$ specifying who must report, when reporting is required, what emissions are to be reported, and in what way emissions are to be reported. It is anticipated that the Reporting Regulation could apply to about 200 facilities in British Columbia. ${ }^{194}$

The regulation requires that facilities emitting more than 10,000 tonnes of $\mathrm{CO}_{2 \mathrm{e}}$ must register and report their GHG emissions. ${ }^{195}$ Those facilities emitting over 20,000 tonnes of $\mathrm{CO}_{2 \mathrm{e}}$ will not only have to register and report 2010 emissions, but will also be required to quantify past emissions for the 2006-2009 years. ${ }^{196}$

Those facilities that become reporting operations are required to continue to report emissions even if the emissions fall below the reporting threshold until those emissions fall below the threshold for three consecutive periods or the operation ceases to carry out the operation that triggered reporting in the first place. ${ }^{197}$

The regulation requires verification of the reporting information for facilities emitting more than 25,000 tonnes of $\mathrm{CO}_{2 \mathrm{e}}$ by an accredited third party. ${ }^{198}$ The regulation requires reporting documents and records to be kept for a minimum of seven years. ${ }^{199}$

\section{d. Carbon Tax}

A key element of the British Columbia government's strategy to reduce GHG emissions is through the revenue neutral carbon tax implemented through the Carbon Tax Act ${ }^{200}$ that came into effect on 1 July 2008. The theory behind the tax is that by putting a price on each tonne of GHG emitted, the economy will respond with an overall reduction in GHG emissions through such actions as reducing fuel consumption, improving efficiency, switching to "cleaner" fuels, or implementing new technologies. The tax is imposed on most carbon-based fuels with the revenue raised being returned to taxpayers through reductions in other taxes (personal and business tax cuts).

The tax is based on the GHG emissions from the combustion of carbon-based fuels and will be phased in over a five-year period. The tax began at a rate of $\$ 10$ per tonne of carbon or carbon-equivalent emissions and rises by \$5 per year, reaching \$30 per tonne by 2012. In practical terms, this amounts to 2.41 cents per litre of gasoline, rising to 7.24 cents per litre by 2012. For diesel and home heating oil, the tax amounts to 2.76 cents per litre rising to 8.27 cents per litre by 2012. The relatively long phase-in period is designed to allow those affected by the tax (businesses and individuals) to adjust their actions and purchasing decisions in advance of the full force of the tax.

B.C. Reg. 272/2009.

See "Reporting Regulation," online: Government of British Columbia <http://www.env.gov.bc.ca/epd/ codes/ggrcta/reporting-reg.htm>.

Reporting Regulation, supra note 193, ss. 6, 9.

Ibid., s. 16.

Ibid., s. 7.

Ibid., s. 19.

Ibid., s. 28.

S.B.C. 2008 , c. 40. 
The specific fuels affected by the tax include aviation fuel, gasoline, heavy fuel oil, jet fuel, kerosene, light fuel oil, methanol, naphtha, butane, coke oven gas, ethane, marketable natural gas, propane, raw natural gas, refinery gas, high heat value coal, low heat value coal, coke, and petroleum coke. ${ }^{201}$

The carbon tax is only payable on the listed carbon-based fuels and combustibles if purchased in British Columbia, ${ }^{202}$ brought into British Columbia, ${ }^{203}$ or if used in British Columbia and is payable at the time of purchase or at the time of use. The Act and regulations establish the following exemptions from the payment of the carbon tax:

(a) fuel that is brought into British Columbia in the supply tank or a supplemental supply tank of a non-commercial aircraft or ship if the fuel is to be used in the operation of the aircraft or ship;

(b) up to "182 litres of fuel that is brought into British Columbia in the supply tank or supplemental supply tank” of non-commercial motor vehicles; ${ }^{204}$

(c) fuel that is purchased in British Columbia for use outside of British Columbia;205

(d) fuel used in the operation of an IFTA commercial vehicle; ${ }^{206}$

(e) fuel that is used "for interjurisdictional air or marine travel or transport"; 207 For example, where a commercial airline operates a flight from Vancouver, British Columbia to Calgary, Alberta via Kelowna, British Columbia and it purchases fuel in Vancouver for this flight, carbon tax is only payable on the portion of the fuel used for the Vancouver to Kelowna portion of the flight;

(f) “[f]uel contained in a sealed, prepackaged container that holds not more than four litres";208

(g) fuel that is used as a feedstock in industrial processes to create other products. ${ }^{209}$ For example, fuel used to make petrochemicals or plastics is not subject to the tax;

(h) fuel that is used for a purpose other than the generation of energy. For example, fuel that is used in the following ways is not taxable:

(i) as a raw material in the smelting of aluminum;

(ii) as a reagent in an industrial floatation process;

(iii) in pipeline pigging; 
(iv) in down-hole operations at a well-site;

(v) to remove natural gas liquids or impurities in the processing of natural gas;

(vi) as a refrigerant in the processing of natural gas;

(vii) if used as a reductant in the production of specified metals (lead and zinc); ${ }^{210}$

(j) cruise ships that use the fuel for interjurisdictional cruises; ${ }^{211}$

(k) ships not engaged in the coasting trade; ${ }^{212}$

(l) visiting foreign armed forces; ${ }^{213}$

(m) diplomatic consular corps;

(n) biofuels and renewable energy; ${ }^{214}$

(o) fuel purchased on-reserve by First Nations purchasers;

(p) specific types of fuel sold to businesses that are "registered consumers" 215 for the type of fuel that they purchase, ${ }^{216}$ such as interjurisdictional air services, interjurisdictional rail services, and businesses that use fuel for an exempt purpose.

Administratively, the tax is applied and collected in the same way that motor fuel taxes are currently applied and collected, namely at the wholesale level, and for marketable gasoline, natural gas, and propane at the retail level, as is the provincial sales tax.

$210 \quad$ Ibid., s. 17.

211 Ibid., s. 19.

212 Ibid., s. 20.

213 Ibid., s. 21. A "visiting force" is defined in the Visiting Forces Act, R.S.C. 1985, c. V-2, s. 2.

214 Carbon Tax Act, supra note 200, s. 1, s.v. "fuel."

215 Ibid., s. 8(4). A "registered consumer" is a person who holds a "registered consumer certificate.” The director may issue such a certificate under s. 20 of the Act, and a person who holds a registered consumer certificate under the Motor Fuel Tax Act, R.S.B.C. 1996, c. 317, s. 37, is deemed to be issued such a certificate under the Carbon Tax Act until 31 December 2008. A registered consumer certificate may be issued by the director to an interjurisdictional rail service, an interjurisdictional air service, or to a purchaser of fuel who uses at least 50 percent of a category of fuel as feedstock (i.e., used as a raw material in an industrial process) or for certain non-energy uses: Carbon Tax Regulation, supra note 208, s. 4(2).

216 The tax is not payable on a transfer if the person is a registered consumer with respect to the type of fuel specified in the person's registered consumer certificate, or to a registered air service or registered marine service with respect to the specified fuels in those certificates. A registered air service is a person who holds a registered air service certificate. A registered air service certificate may be issued by the director to a person who owns or operates a commercial air service that offers air transportation of passengers or goods to the public for a fee if: "at least $50 \%$ of the fuel used in the flights of all aircraft owned or operated by the person that began or ended in British Columbia was used for flights that did not both begin and end in British Columbia"; "the person holds a licence issued by the Canadian Transportation Agency and an operating certificate from Transport Canada”; and all flights offered are authorized by those agencies: Carbon Tax Regulation, ibid., s. 5. A registered marine service is one that has a registered marine service certificate. Such a certificate may be issued by the director to a person who owns or operates a commercial marine service that offers marine transportation of passengers or goods to members of the public for a fee and where at least 50 percent of all of the trips of the ships owned or operated by the person that began or ended in British Columbia did not have an "intraprovincial leg"; or the person owns or operates a commercial marine service for the public where are at least 50 percent of all trips of the ships owned or operated that began or ended in British Columbia included an "interjurisdictional leg": ibid., s. 6. 


\section{e. $\quad$ Other Initiatives}

Pursuant to the BC Energy Plan, the Greenhouse Gas Reduction (Renewable and Low Carbon Fuel Requirements) Act, ${ }^{217}$ and the Renewable Fuel Requirements Regulation ${ }^{218}$ require fuel suppliers of gasoline or diesel to ensure that renewable fuel is at least 5 percent of that fuel and that the carbon intensity of fuels meets certain prescribed standards.

British Columbia has also established framework legislation to set vehicle emission standards equivalent to those in California through the Greenhouse Gas Reduction (Vehicle Emissions Standards) Act. ${ }^{219}$

The policy objectives of energy conservation and a focus on alternative clean energy is carried out through changes to the Utilities Commission Act, ${ }^{220}$ which task the British Columbia Utilities Commission with specifically considering the government's energy objectives.

\section{f. Flaring, Incineration, and Venting}

Flaring is the controlled burning of natural gas, while venting describes natural gas that is released without flaring. Both release GHG emissions into the atmosphere and these methods are used in a range of situations. For example, natural gas may also be found in an oil well and when the oil comes to the surface, the gas may escape through the well. If the amount of gas is not economical to build a pipeline or facility to capture it and transport it to market, it is flared or vented. Flaring is also part of plant maintenance and safety at facilities such as gas plants, upgraders, and oil batteries.

The BC Energy Plan set a goal of eliminating all routine flaring by 2016 with an interim target of a 50 percent reduction by 2011. Routine flaring is gas that meets an economic threshold for conservation, which is consistent with the Global Gas Flaring Reduction (GGFR) Partnership voluntary standard. ${ }^{221}$ In 2005, British Columbia’s Oil and Gas Commission (OGC) became a GGFR partner and since that time has developed a Country Implementation Plan. ${ }^{222}$ Although Alberta has addressed the flaring issue for some time through Alberta's Directive 060: Upstream Petroleum Industry Flaring, Incinerating, and Venting, ${ }^{223}$ the OGC's Flaring, Incinerating and Venting Reduction Guideline for British Columbia became effective 5 March $2008 .^{224}$ The Guideline generally applies to flaring, ${ }^{225}$

Supra note 107.

B.C. Reg. 394/2008.

S.B.C. 2008, c. 21.

R.S.B.C. 1996, c. 473.

The World Bank, Global Gas Flaring Reduction: A Voluntary Standard for Global Gas Flaring and Venting Reduction (Washington, D.C.: The World Bank, 2004).

British Columbia, Oil and Gas Commission, Flaring, Incinerating and Venting Reduction Guideline for British Columbia (Fort St. John: Oil and Gas Commission, 2008) at 2.

Alberta, Energy Resources Conservation Board, Directive 060: Upstream Petroleum Industry Flaring, Incinerating, and Venting (Calgary: Energy Resources Conservation Board, 2006) [Directive 060]. Supra note 222.

Flaring is the controlled burning of natural gas that cannot be processed or sold. It is restricted primarily to short-term well testing, well workovers, maintenance, or emergency situations: see British Columbia, Oil and Gas Commission, Information Sheet 16: Flaring, Incineration and Venting, at 1, online: Oil Gas Commission <http://www.ogc.gov.bc.ca/documents/publications/Fact\%20Sheets/16_Flaring,\%20 Incineration\%20and\%20Venting.pdf $>$ [OGC Information Sheet 16]. 
incineration, ${ }^{226}$ and venting ${ }^{227}$ of natural gas at any well-site, facility, or pipeline regulated by the Petroleum and Natural Gas Act ${ }^{228}$ and the Pipeline Act. ${ }^{229}$ The objective of the Guideline is to conserve natural gas and set out the approval criteria required to flare, incinerate, or vent gas. To put this in context, in Alberta, there was a 70 percent reduction in flaring levels from 1996 to 2003 as a result of a range of measures, including Alberta's Directive 060. ${ }^{230}$

\section{g. Carbon Sequestration}

The British Columbia government has begun to explore initiatives for biotic sequestration and carbon capture and storage, which is supported by funding for research. In relation to CCS, research includes a feasibility study for carbon capture and storage technology for natural gas production. ${ }^{231}$ At a regulatory level, all coal-fired electricity generation facilities must be able to capture and store carbon, ${ }^{232}$ though at this time other facilities do not have this requirement.

\section{Challenges AND OPPORTUNities FOR THE OIL AND GAS SECTOR}

\section{A. Alberta}

One of the central challenges created by the current Alberta regulatory scheme is its focus on made in Alberta solutions. As a result, whether it is with respect to carbon sequestration or carbon offsets, only those projects occurring in Alberta are supported. ${ }^{233}$ The net result of this for national and international companies in the oil and gas sector is that their approach to GHG reductions on an integrated national or international scale may be irrelevant, as their operations and activities in Alberta will be the sole focus of the assessment of their GHG intensity for compliance purposes. This "island Alberta" situation imposes limits on the ability of companies to manage their global carbon profile in an integrated and market wise manner.

Incineration occurs when waste gas is mixed with air at a controlled rate in a combustion chamber designed to ignite and burn the gas: see ibid.

Venting is the release of gases directly into the atmosphere without flaring or incinerating. It typically results from the treatment and storage of oil, operations at natural gas wells, and pipelines: see ibid.

R.S.B.C. 1996, c. 361.

R.S.B.C. 1996, c. 364.

See "Flaring \& Venting," online: CAPP <http://www.capp.ca/environmentCommunity/airClimate Change/Pages/FlaringVenting.aspx>.

British Columbia, Ministry of Finance, Budget and Fiscal Plan 2009/10-2011/12 (Victoria: Ministry of Finance, 2009), online: Government of British Columbia <http://www.bcbudget.gov.bc.ca/2009/bfp/ 2009_Budget_Fiscal_Plan.pdf>.

Bill 31, Greenhouse Gas Reduction (Emissions Standards) Statutes Amendment Act, 2008, 4th Sess., 38th Parl., British Columbia, 2009, cl. 2 (assented to 29 May 2009), S.B.C. 2009, c. 20 (amending the Environmental Management Act, S.B.C. 2003, c. 53).

Only offsets occurring in Alberta may be used for compliance purposes: Emitters Regulation, supra note 125, s. 7(1)(a). The Province has also made it clear that any portion of a CCS project outside the boundaries of Alberta is ineligible for funding under the CCS program: see CCS Storage Program Info. Package, supra note 91 at 5 . 
This Alberta-only focus, although perhaps constitutionally necessary, has also limited the extent to which the offsets trading scheme can truly operate as a "market" for any of Alberta's large-scale emitters. International commentators have suggested that size does matter when attempting to establish a functioning carbon market:

\footnotetext{
The principal reason for extending emission trading schemes to as broad a range of countries and sectors as possible is one of economic efficiency. The more sources of emissions that are included in the scheme, the more opportunities there are to identify and make use of abatement opportunities with lower costs. Increased numbers of participants in the market also improves liquidity with commensurate benefits for price stability and economies of scale in the provision of market infrastructure, such as trading platforms and standardised contracts. $^{234}$
}

Consequently, barriers to harmonization between the Alberta offset and credits system, the future federal offsets system, North American systems such as the WCI and potential global trading systems create uncertainty, inefficiency, duplication, overlap, and the distinct possibility that the oil and gas sector may be subject to contradictory regulatory compliance requirements in the near-term. This potential patchwork is often a concern in respect of environmental standards, but is a particularly acute cause for concern when the regulatory framework is attempting to establish a reasonable market.

However, as difficult as harmonization across Canada may be, the experience of Alberta with issues such as developing quantification and verification protocols to create credible offsets, establishing a ceiling price for carbon, determining what the threshold for reporting and limits should be, addressing the shortage of third party carbon offset verifiers, and determining the role of regulators and registries in markets that are intended to function primarily based on transactions between private parties have been instructive. Learning from these experiences can ensure that a more solid foundation for nationally or internationally integrated frameworks is established at the outset.

The Province's approach to CCS clearly creates both challenges and opportunities. As noted previously, the Province's hopes for a return to significant growth in the oil and gas sector, while reducing the carbon footprint of the energy produced, is largely dependent on the success of CCS. Perhaps, as illustrated by the recent reluctance of large oil sands producers to develop the initial projects, uncertainty regarding the many issues associated with CCS, including technological feasibility, costs, regulatory requirements, and long-term liability are currently limiting the extent to which the sector shares the Province's enthusiasm for this solution. Given the current state of financial markets, greater certainty that transcends individual project approvals is likely required before the challenge of GHG reductions is matched by the opportunity of CCS. 
These challenges are considerable but not insurmountable. The stakes for the oil and gas sector, and in turn, the Province, are very high as the quest to turn "black gold" to green, in every sense, continues.

\section{B. BRITISH COLUMBIA}

British Columbia's oil and gas sector will face climate change related challenges at the exploration and operational level as changing climatic conditions require adaptation of traditional exploration and production methods. At a British Columbia economy level, the government's policies and legislative initiatives are designed to shift demand and reliance from carbon intense fuel and activities to cleaner, less carbon intense sources, which may also have an effect on the sector.

The British Columbia oil and gas sector will be affected by the cap and trade system in the long-term, while in the short-term, the sector will have registration and reporting requirements. This reporting includes upstream oil and gas, including gas transmission and distribution systems, and petroleum refining. Although this reporting will only apply to facilities emitting over 25,000 tonnes of $\mathrm{CO}_{2 \mathrm{e}}$ from 2009 onwards, the proposed regulation is anticipated to capture upstream oil and gas facilities that emit 3,000 tonnes of $\mathrm{CO}_{2 \mathrm{e}}$ per year.

The British Columbia carbon tax is designed to shift demand away from carbon fuel sources. The tax is payable on a range of petroleum-based fuels and natural gas. However, the tax is not payable if the fuel is used for a purpose other than to generate energy. For example, it is not taxable if used in pipeline pigging, in down-hole operations at a well-site, to remove natural gas liquids or impurities in the processing of natural gas, or as a refrigerant in the processing of natural gas.

With a new United States federal administration, which appears to have an interest in taking a stronger lead on the climate change file, there is some uncertainty as to the future direction of the regional WCI cap and trade system, which will in turn call into question British Columbia's own cap and trade system, particularly if the Canadian federal government follows the U.S. lead and sets up a Canadian federal system that is designed to be compatible with any U.S. federal system. One of the largest challenges will be compatibility or harmonization of these different systems.

Although the British Columbia government has taken concrete steps to reduce GHG emissions in the oil and gas sector, primarily through the reduction, and ultimate elimination, of routine flaring, this has to be weighed against British Columbia's encouragement of additional oil and gas development in new basins and possibly in the offshore together with "royalty breaks" or credits, which will increase to $\$ 120$ million in $2009 .{ }^{235}$ If such development proceeds, it may offset the GHG emission reductions from the flaring initiatives. Having said that, some non-government organizations believe that there are more GHG reductions available in this sector through reducing fugitive gases, sequestration and

235 See Claudia Cattaneo, "BC Hikes Royalty Breaks to Woo Oil and Gas Industry” Financial Post (2 March 2009), online: Financial Post <http://www.financialpost.com/story.html?id=1345807>. 
compressor technologies and policies, and energy efficiency improvements at oil and gas plants. $^{236}$

In terms of new oil or gas projects, any required environmental assessment will have to address the uncertainty of climate change effects and the paucity of climate change data. Any project that increases GHG emissions is also likely to be very carefully scrutinized in light of the government's objectives to reduce GHG emissions, and these policies may be the basis upon which groups opposed to the project may challenge the assessment and any decision. Climate change policies may translate into additional GHG reduction conditions in any approvals issued for projects, possibly including carbon capture and storage.

A sector opportunity lies in eliminating or capturing fugitive emissions or small leaks from existing natural gas facilities and infrastructure, which is consistent with the BC Energy Plan and the new flaring and venting guidelines that have been introduced. Not only does this have an economic benefit in being able to capture and ultimately sell more product, such actions may translate into carbon credits for the company taking such action. For example, ConocoPhillips has a Fugitive Emissions Reduction Program that has operated since 2006 to find, measure, and reduce or eliminate these fugitive emissions at 22 of its processing plants. $^{237}$

Carbon capture and storage perhaps represents the industry's greatest opportunity and yet also its biggest challenge in British Columbia. As an opportunity, it is a way to address the increasing GHG emissions from the oil and gas sector by capturing those emissions and either storing them or putting them to use in improving other reservoirs. Although some companies are beginning to capture $\mathrm{CO}_{2}$ and store it underground or transport it to conventional oil and gas wells to help recover more resources from those wells, ${ }^{238}$ it appears that there is still considerable work to be done to make this technology cost-effective and readily available.

With the environment taking a back seat to the (flagging) economy and the federal government waiting to see what the American system will look like, the uncertainty grows.

\section{CONCLUSION}

As this article illustrates, the approaches to climate change law and policy in our tale of two provinces reflect more than regional variation in emissions profiles and geography. Fundamental philosophical differences underlie the approaches of Alberta and British Columbia. Clearly Alberta's central focus is on made in Alberta solutions, with an exclusively Alberta-based offset trading scheme, a clear link between GDP and intensitybased limits, and a reduction plan (CCS) that will take considerable lead time to deploy. The

See e.g. Alison Bailie et al., Mind the Gap: A Blueprint for Climate Action in British Columbia (Drayton Valley: The Pembina Institute, 2007), online: The Pembina Institute <http://pubs. pembina.org/ reports/mindthegap-full.pdf $>$.

237

238

See "Managing Fugitive Emissions," online: CAPP < http://www.capp.ca/energySupply/innovation Stories/Pages/managingFugitiveEmissions.aspx>.

EnCana Corporation has been using $\mathrm{CO}_{2}$ at the Weyburn project in southeast Saskatchewan to recover more oil from an old reservoir: see "Carbon Capture \& Storage," online: CAPP <http://www.capp.ca/ energySupply/innovationStories/Pages/capturingStoring Carbon.aspx>. 
current vision in British Columbia differs markedly with the recognition of the benefit of participating in trading schemes extending beyond its borders and the use of a carbon tax to change consumer behaviour while modifying the Province's general tax structure for all residents.

From the perspective of the oil and gas industry, identifying the risks and opportunities presented by climate change is increasingly difficult when faced with such varied approaches. In addition, to be viable, trading schemes must be easily integrated with frameworks from other sectors and jurisdictions. As noted in a 2008 review of the issues associated with increasing the integrity of carbon offset trading schemes:

Where practical, emerging regulatory regimes should be designed to be as compatible as possible with other existing and emerging regimes, both domestically and internationally (as long as those regimes have high environmental integrity). In particular, mitigation policies should build on and enable linkage with the international frameworks already in place. Offset standards and markets should work towards the recognition of a globally fungible offset credit commodity, which will increase global liquidity and market efficiency. ${ }^{239}$

Despite the recognized need for harmonization, particularly with respect to market-based instruments, with such fundamental differences between the existing provincial regimes, the task of harmonization on a federal level remains daunting. However, it is hoped that notwithstanding the obstacles, the lessons learned from the experiences of the first provinces off the mark will serve to shape a wise path forward for all sectors of the economy and all Canadians. 